\title{
Earthquake risk scenarios in urban areas: a review with applications to the Ciutat Vella district in Barcelona, Spain
}

\author{
N. Lantada ${ }^{1}$, L.G. Pujades ${ }^{2}$ and A.H. Barbat ${ }^{3}$ \\ ${ }^{1}$ Division of Geotechnical Engineering and Geosciences, Civil and Environmental Engineering, Universitat \\ Politècnica de Catalunya, C. Jordi Girona 1-3, Building D2, 08034 Barcelona, Spain \\ Tel. (+34) 934016926 Fax (+34) 934017251 nieves.lantada@upc.edu \\ ${ }^{2}$ Division of Geotechnical Engineering and Geosciences, Civil and Environmental Engineering, Universitat \\ Politècnica de Catalunya, C. Jordi Girona 1-3, Building D2, 08034 Barcelona, Spain \\ Tel. (+34)934017258 1luis.pujades@upc.edu \\ ${ }^{3}$ Division of Mechanics, Continuum Mechanics and Structures, Civil and Environmental Engineering, Univer- \\ sitat Politècnica de Catalunya, C. Jordi Girona 1-3, Building C1, 08034 Barcelona, Spain \\ Tel. (+34)934016496 alex.barbat@upc.edu
}

\begin{abstract}
The vulnerability index and capacity spectrum based methods used to assess the expected physical damage in dwellings are revisited, and their main advantages and shortcomings are analysed and discussed. Then, a vulnerability index based method is used to assess the expected damage in the oldest district of Barcelona, Spain. The risk analysis is performed for earthquake scenarios defined by macroseismic intensities of V, V-VI, VI, VI-VII and VII, to design seismic emergency plans. According to the Spanish Seismic Code, the basic peak ground acceleration for a 475 year return period is $0.04 \mathrm{~g}$, which corresponds to an intensity of VI. Thus, the expected physical damage is quantified and its impact on population and other quantities, such as debris and economic cost, are studied. In spite of the low-to-moderate seismic hazard in Barcelona, the results show that the risk is high, due to the high exposure and vulnerability of the built environment.
\end{abstract}

Keywords urban seismic assessment, building vulnerability, vulnerability index method, damage probability assessment, risk scenarios 


\section{Introduction}

Several seismic events, which occurred in urban areas with a low-to-moderate seismic hazard, were relatively small and far from extraordinary, caused enormous, tragic damage due to the high vulnerability of buildings. Recent disastrous events in Europe, such as the Amatrice earthquake on 24 August 2016, and the Ischia earthquake of magnitude 4.2 on 21 August 2017 with 2 deceased, 39 injured and more than 2,500 made homeless (The Guardian online, 22 August 2017), have proved this fact.

Therefore, large-scale assessment procedures should be preferred over more accurate methods designed to evaluate the seismic risk of individual buildings. However, it is imperative to focus the seismic assessment on the most vulnerable areas of towns, which typically encompass the historical centres. In these centres, there is generally a high concentration of old stone or brick masonry buildings, which are the most representative and vulnerable construction type (Uva et al., 2016; Maio, 2016). Preserving a large number of old masonry buildings built in active seismic zones is one of the problems that many municipalities face today. To solve these critical issues, it is very important to evaluate the earthquake resistance of these buildings, to strengthen them with structural interventions for long-term prevention and/or to prepare emergency plans using realistic earthquake scenarios. Services related to structural health monitoring that were proposed for historical city centres by Carnimeo et al. (2015a and b) and Gattulli et al. (2015) may help to protect buildings from seismic events, and to validate the performance of interventions.

What is required is a relatively fast but accurate seismic vulnerability assessment. Currently, many risk analysis methods consider a large territorial scale approach. However, information contained in larger scale plans could become useless if it does not reflect the local situation, which changes rapidly over time in urban areas. This could negatively affect the risk assessment, which may be too general and ineffective on a minor or local scale (Pilone et al., 2017). 
In addition, strategic paths that are clearly identified in the ordinary road network have a high potential impact on emergency planning, because they can ensure access to strategic elements after a seismic event (Ferlito and Pizz, 2011). In these cases, the debris generated by damaged buildings may be a substantial obstacle to enabling the minimum mobility of emergency services required to reach the resident population.

To determine expected damage scenarios resulting from likely earthquakes, the database must contain information such as hazard results, geotechnical characteristics of the ground, structural characteristics of buildings, population exposure, and geographical distribution of the population in working units. The use of different sources of information makes it difficult to integrate all the input data, which vary in time and scale. Data is usually integrated more efficiently by appropriate software, such as Geographical Information Systems (GIS). GIS software is a useful tool to obtain an immediate, easy-to-read overlap of the different thematic layers (Pilone et al., 2017), which can show the key risk points simply, thus facilitating the analysis and dissemination of results (Rivas-Medina et al., 2013).

\subsection{Background}

The first methods based on vulnerability indexes were proposed by Bendetti and Petrini (1984), who used extensive damage survey data corresponding to several strong earthquakes in Italy. The methods differentiate buildings with the same structural type by means of a vulnerability index $\left(V_{1}\right)$. ATC-13 (ATC-13, 1985) classifies buildings according to their type, material, or year of construction. At a later date, the Gruppo Nationale per la Difesa dai Terremoti ${ }^{1}$ (GNDT, 1994; Bernardini 2000) developed a method which identifies the type of building and defines its vulnerability class (i.e., A, B, C) (Giovinazzi and Lagormarsino, 2002). Subsequently, the Risk-UE Project: "An advanced approach to earthquake risk scenarios with application to different European towns" (Mouroux and Lebrun, 2006a, b), developed specific risk analysis

\footnotetext{
${ }^{1}$ Gruppo Nazionale per la Difesa dai Terremoti (https://emidius.mi.ingv.it/GNDT2/Menutree/Home.htm)
} 
methods for Europe, which were applied to the cities of Barcelona, Bitola, Bucharest, Catania, Nice, Sofia, and Thessaloniki. Although these methods have some aspects in common, they are different from other methods promoted and proposed in other regions and countries, such as Hazus 99 (FEMA, 1997; FEMA/NIBS, 2002), which is designed to be applied in the United States.

The Risk-UE project proposed two approaches to the seismic vulnerability assessment of existing buildings: Level Method 1 (LM1), which considers the seismic scenario in terms of macroseismic intensity, and buildings' strength in terms of vulnerability indices $V_{l}$; Level Method 2 (LM2), which considers the seismic action in terms of response spectra, and the strength of the buildings in terms of capacity and fragility curves. LM1, named the vulnerability index method (VIM) in this paper, is specific to and typical of Europe, and gathers the experience of seismic risk studies based on vulnerability indexes, damage factors and damage probability matrices (DPM). This method is inspired by and based on the European Macroseismic Scale (EMS-98) (Grünthal, 1998) and allows the study of risk scenarios in a relatively simple way. The VIM is the method applied in this study and is described briefly below.

\subsubsection{The vulnerability index method (VIM-LM1)}

Since the VIM (LM1) was proposed (Mouroux and Lebrun, 2006 a,b; Lagomarsino and Giovinazzi, 2006), it has been applied to many urban areas at regional and local scale. Specifically, in north-eastern Spain, the method was applied to the Cerdanya region (Goula et al. 2008; ISARD, 2006) and the Principality of Andorra (González, 2010) as part of research on the ISARD Project. Both areas are in the Pyrenean domain. In the SisPyr project, the method was applied to the Val d'Aran region and Girona city (Montfort et al., 2012). Chiefly, the VIM method has been applied in European and African cities of the Mediterranean region. Some examples are the assessments carried out in the cities of Al Hoceima and Imzouren in Morocco (Cherif et al., 2017), and in the cities of Lorca (Tomas et al., 2017), Barcelona (Lantada et al., 2009a), Valencia (Guardiola-Víllora and Basset-Salom, 2015) and Granada and Velez in southern Spain 
(Feriche, 2012 and Feriche et al., 2009). Moreover, the VIM has been used in vulnerability assessments of the current building stock in historical centres, as in the ANTAEUS Project (Uva et al., 2016) in the Province of Foggia (Puglia, Southern Italy); and for the vulnerability assessment of old masonry buildings in the historical centre of Faro (Maio, 2016) and Lisbon (Simoes et al. 2016) in Portugal.

These studies estimate the vulnerability of buildings based on data collected by field surveys, or taken from cadastral databases. This information usually contains the structural type of building, number of floors, regularity in horizontal geometry, and height and building position in the aggregate and soft floor, among others. Information can also be extracted from high-resolution satellite/aerial images (Polli et al. 2009; Dell'Acqua et al., 2013). Recently, Tomas et al. (2017) proposed new behaviour modifiers based on the damage observed in the 2011 earthquake in Lorca (Spain).

These assessments are an excellent source of information that civil protection services may use to design and improve their emergency plans in case of earthquake. The Barcelona Civil Protection Service used the seismic evaluation results obtained as part of the Risk-UE Project to design Barcelona's Municipal Action Plan for seismic risk (PAM ${ }^{2}$ ) (PAEM, 2016). Results from these kind of assessments were also used for Valencia's Special Plan against seismic risk, approved in 2011, which recommends the creation of specific plans for several municipalities. The study carried out in the residential district of the Eixample by Guardiola-Víllora and Basset-Salom (2015) led to the project being extending to the rest of the city of Valencia, and studies by Feriche (2012) and Feriche et al. (2009) helped to improve local seismic emergency planning in Granada and Velez cities in southern Spain.

\footnotetext{
2 "Pla d'Actuació Municipal per risc sísmic, PAM" in Catalan, former "Pla d'Actuació d’Emergències Municipal, PAEM"
} 


\subsubsection{The capacity spectrum based method (CSBM-LM2)}

Other ways of assessing expected seismic damage in existing buildings are based on the capacity spectrum method (CSM) (Freeman, 2004). The CSM considers seismic action in terms of $5 \%$ damped response spectra; and the seismic quality of the buildings, that is, their vulnerability, by means of capacity spectra. Capacity spectra are the acceleration-displacement format of capacity curves, which are obtained using the well-known pushover analysis. In summary, the CSM allows a simplified, straightforward assessment of the spectral displacement that a given earthquake, defined by its $5 \%$ damped response spectrum, would produce on a given building, defined by its capacity spectrum. Furthermore, capacity spectra are often used to define fragility curves (FEMA/NIBS, 2002), allowing the expected seismic damage and risk to be quantified. The Level Method 2 (LM2) considers four non-null damage states: Slight, Moderate, Extensive and Complete. The LM2 method developed in the framework of the European Risk-UE Project is based on a CSM in which fragility curves are obtained in a simplified way from the bilinear capacity spectra (Milutinovic and Tredafiloski, 2003), which are defined by means of the yielding and ultimate capacity points (Barbat et al., 2006; Lagomarsino and Giovinazzi, 2006). This method has been applied numerous times to provide fragility curves for northern European building stock (Lestuzzi et al., 2017), various types of buildings in southern Europe, studies in Barcelona (Barbat et al., 2008; Lantada et al., 2009b, Pujades et al., 2012, Irizarry et al., 2010), and a recent study by Simoes et al. (2017) for three kinds of old masonry buildings in Lisbon.

\subsubsection{LM1 or LM2}

LM1 and LM2 are also referred to as empirical and mechanical methods respectively (Lagomarsino and Giovinazzi, 2006). The empirical LM1 method is extremely versatile in characterizing the seismic behaviour of buildings, as the representative vulnerability index can be modulated for each individual building, by means of regional and building modifiers. Therefore, a specific basic class of building can cover a broad 
range of indexes and, thus, regarding the EMS-98 macroseismic scale, a broad range of vulnerabilities. The LM1 can be applied to vast urban areas rapidly and easily, and generates very reliable scenarios when interpreted from a probabilistic point of view. It requires less information and allows rough simplifications of both the seismic input and the vulnerability of buildings.

The LM2 is the method adopted in Hazus methodology (Fema-NIBS 2002), and it could be considered an advanced approach that incorporates new methodologies to analyse the damage and the seismic risk in large conurbations. However, LM2 requires more information of a higher quality on both the seismic actions and the structural details of the buildings. Acceleration data on seismic actions are required. Detailed mechanical models and non-linear static structural analysis programmes on buildings are also required, which imply great simplifications. Thus, although LM2 is a powerful method, it needs a great amount of high quality data and it is expensive in terms of computing time.

To decide whether to use LM1 or LM2 in the seismic risk assessment of a given seismic urban area, it is important to consider that both methods provide results with similar levels of accuracy that correlate well, despite the differences. In a substantial application, both methods can identify the most vulnerable parts of a city and the most vulnerable city among a group of cities. However, when a single building has to be evaluated, LM2 is preferable, especially in the case of cultural heritage and essential buildings.

Concerning the consistency of LM1 and LM2 methods, Lantada et al. (2009b) compared the results of applying both methods to Barcelona (Spain), which is in a low-to-moderate seismic hazard zone. The difference between both scenarios was negligible, but for more severe scenarios the differences may be significant (Lantada, 2007). Lestuzzi et al. (2016) also compared the results for two cities in the canton of Valais, which has the highest seismicity within Switzerland. The discrepancy in the results indicates that damage may be overestimated by the LM2 method. More research is needed to identify the real causes of the discrepancy, by focusing on applications in regions with moderate seismicity. These two studies 
agree that both methods can identify the most vulnerable parts of a city, and both provide excellent overall results that show a reasonably good correlation with the main features of the built-up environment of the urban area under study.

\subsection{Objectives}

The present paper estimates the impact of seismic scenarios on the dwellings and population of the oldest district of Barcelona (Spain), the "Ciutat Vella", which is the downtown area of the city. This urban area is in a low-to-moderate seismic hazard region, and over $90 \%$ of the buildings are old, unreinforced stone or masonry edifices. The ultimate objective of this study was to provide useful information on seismic risk assessment for Barcelona Council's Civil Protection Service, so that the Municipal Action Plan (PAM) could be updated (PAEM, 2016). The main purpose of the Action Plan is to provide a quick, effective response that minimizes potential damage to people, property and the environment, and restores basic services to the population in the shortest possible time.

Seismic action is considered in terms of macroseismic intensity, according to the European scale (EMS-98) (Grünthal 1998), and buildings are characterized by means of vulnerability indexes. In other words, the first-level method (LM1) that was developed as part of the EU-Risk project, is used (Lantada, 2007; Milutinovic and Trendafiloski, 2003; Mouroux et al., 2006a; and Mouroux et al., 2006b). In fact, the LM1 method was preferred by authorities in the municipality because it is simple, versatile and easy to understand the severity of seismic actions and interpret the results on vulnerability and expected damage. Moreover, LM2 applications to urban areas are usually performed by grouping constructions into a small number of building classes, which severely smooths the obtained results. If constructions were not grouped, the application of LM2 would require a vast number of computations to adequately represent the capacity and fragility of each individual building. Therefore, the application of CSBM was not considered. 
The analysis was executed on a GIS building-by-building basis, but the results were given at district and neighbourhood level. The analysis at such a local scale was possible due to an accurate, complete database on the structural types and population provided by Barcelona City Council's Municipal Institute of Information Technology (IMI). In addition to GIS capabilities to assist the management and display of this database, customized GIS tools have been developed to obtain spatial parameters from buildings' geometry, to calculate some behaviour modifiers of the vulnerability index. Results include estimation of building vulnerability, direct physical damage, generated debris, economic cost, and the effects on the population, including the number of injured and deceased people, and those made homeless.

As mentioned above, this information has been used to update the Municipal Action Plan for the city of Barcelona (PAEM, 2016). Subsequently, the results were also used in a holistic evaluation of seismic risk (Jaramillo et al., 2016).

\section{Vulnerability Index Method}

As pointed out above, the LM1 gathers the experience of seismic risk studies based on vulnerability indexes, damage functions and damage probability matrices (DPM), so that risk scenarios can be studied in a relatively simple way. Recall that the VIM defines seismic action by means of macroseismic intensity, that is, by means of a sole parameter.

The VIM introduces a vulnerability index to represent and quantify whether a building belongs to a certain vulnerability class. It uses average semi-empirical vulnerability functions, which, for a given vulnerability index, relate macroseismic intensity and expected damage. In other words, these damage functions relate the degree of average damage to types of vulnerability, based on macroseismic intensity and the vulnerability index. DPM define the probability of occurrence of a given damage grade. In this method, the qualitative matrices proposed in the EMS-98 are generated by modelling each type of vulnerability through beta distributions, which are adjusted in such a way that they are equivalent to a binomial distribution. 


\subsection{Seismic action}

Seismic action is considered in terms of the European Macroseismic Scale (EMS-98). Earthquake scenarios can be chosen based on likely earthquakes in the study area. Deterministic or probabilistic earthquake scenarios may be analysed. Deterministic scenarios are defined in such a way that they are representative of major historical earthquakes. Usually, the highest seismic intensity experienced in the study area is chosen, but other earthquake scenarios may be selected too. Probabilistic scenarios correspond to earthquakes with a predefined probability of occurrence. Usually, the 475-year return period earthquake is chosen, that is, macroseismic intensity with a $10 \%$ probability of occurrence in 50 years. This characteristic earthquake is frequently used in seismic design and risk assessment, and is usually defined in seismic regulations.

For both kinds of scenarios, deterministic and probabilistic, when the hypocentre is outside or far from the studied area, the effect of attenuation of seismic intensity with distance (Sponheuer, 1960; Secanell et al., 2004) should be considered. Soil or other amplification effects must also be taken into account.

\subsection{Vulnerability}

Vulnerability index based methods draw on macroseismic intensity scales. Here, the VIM is based on the EMS-98 intensity scale (Grünthal, 1998). In EMS-98, buildings are classified according to their main structural features. Four main building types are considered: masonry, reinforced concrete (RC), steel, and wood structures. Vulnerability is set according to six vulnerability classes, which are labelled with letters A-to- $F$, where class $A$ is the most vulnerable, and $F$ the least. Different buildings of the same type may pertain to different vulnerability classes, depending on their specific materials, structural properties and/or construction quality. The most likely class and probable and least probable vulnerability ranges are provided. The following damage grades are considered: 0. Null, 1. Slight, 2. Moderate, 3. Heavy, 4. Very 
heavy and 5. Destruction. Then, expected damage is described in an imprecise, inaccurate way. For instance, a typical sentence in the EMS-98 scale, for intensity VIII, which is labelled as Heavily Damaging, is: "Many buildings of vulnerability class C suffer damage of grade 2; a few of grade 3". Because the expected damage in not fully defined for all intensities and all vulnerability classes, and definitions of quantity are given in a wordy way, vulnerability and expected damage are established in a qualitative, diffuse and incomplete way in the EMS-98 scale.

Based on this context (Grünthal, 1998) and studies completed as part of the Risk-UE project (Giovinazzi and Lagomarsino, 2002; Milutinovic and Trendafiloski, 2003; Giovinazzi, 2005), Lagomarsino and Giovinazzi (2006) proposed the VIM, which is a robust method for assessing expected seismic damage and risk in urban areas in a straightforward way. The assumption that expected damage follows a binomial distribution solves the problem of incompleteness; and enables complete damage probability matrices (DPM) to be obtained for every building class and each macroseismic intensity. In addition, fuzzy theory elements allow diffuse aspects to be controlled. The particular vulnerability class that a specific building belongs to is now defined by a vulnerability index. This vulnerability index is normalized in such a way that it takes values between 0 (least vulnerable) and 1 (most vulnerable). Extreme values below 0 and over 1 are allowed for special vulnerable or strengthened buildings. The Risk-UE technical manuals (see for instance Milutinovic and Trendafiloski, 2003) and VIM practical applications (see for instance Lantada, 2007) propose adequate values of the vulnerability indices for buildings in specific building typology matrices (BTMs). In fact, these vulnerability indices are related to the values of a membership parameter, $\chi$, of the vulnerability classes of the EMS-98 scale: $\chi$ takes values between 1 , total membership; and 0, no-mem-

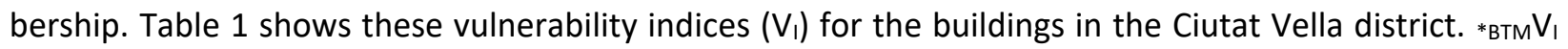
$(\chi=1)$ is the most likely value, $\left[-\right.$ втм $V_{1},+$ втм $\left.V_{1}\right](\chi=0.5)$ defines the interval in which plausible vulnerability

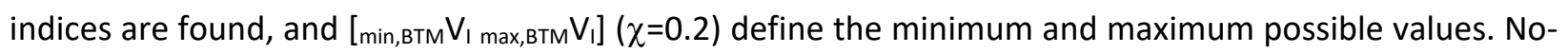
ticeably, the method provides schemes and guidelines to fix the vulnerability index limits, as suggested 
here, or to calibrate new ones, considering the quantity and quality of the available information, as well as the specific features of the buildings that are analysed. Thus, every building is characterized by means of a specific vulnerability index, which is obtained from a basic index, ${ }_{{ }_{\mathrm{B}} \mathrm{BM}} \mathrm{V}_{\mathrm{I}}$ in Table 1 , and adequate modifiers so that this central value can be adapted to the specific age, geometry, location and other mechanical properties of the building, within the range of likely and possible allowable values. Specifically, in this study, regional and behaviour modifiers have been considered. The first modifier allows for construction customs and seismic codes in force in the region at the time the building was constructed, while the behaviour modifier considers the contribution to the vulnerability index of peculiar features of the building (building modifier), and other attributes related to its position in a block or aggregate (location modifier).

Table 1. Structural typologies and vulnerability classes of dwelling buildings in Ciutat Vella.

\begin{tabular}{|c|c|c|c|c|c|c|c|}
\hline \multirow[b]{2}{*}{ Building type } & & & \multicolumn{5}{|c|}{ Vulnerability index $\left(V_{\nu}\right)$} \\
\hline & & & $\min B T M V_{l}$ & $-B T M V_{l}$ & *BTMV & $+B T M V_{l}$ & $\max , B T M V_{1}$ \\
\hline \multirow[t]{4}{*}{ Unreinforced masonry } & Wooden slabs & M3.1 & 0.460 & 0.650 & 0.740 & 0.830 & 1.020 \\
\hline & Masonry vaults & $M 3.2$ & 0.460 & 0.650 & 0.776 & 0.953 & 1.020 \\
\hline & Composite steel and masonry slabs & M3.3 & 0.460 & 0.527 & 0.704 & 0.830 & 1.020 \\
\hline & Reinforced concrete slabs & M3.4 & 0.300 & 0.490 & 0.616 & 0.793 & 0.860 \\
\hline \multicolumn{2}{|c|}{ Reinforced concrete with irregular frames } & $\mathrm{RC} 3.2$ & 0.060 & 0.127 & 0.522 & 0.880 & 1.020 \\
\hline \multicolumn{2}{|c|}{ Steel frame and unreinforced masonry infill walls } & $\$ 3$ & 0.140 & 0.330 & 0.484 & 0.640 & 0.860 \\
\hline \multicolumn{2}{|c|}{ Steel and RC composite system } & $\$ 5$ & -0.020 & 0.257 & 0.402 & 0.720 & 1.020 \\
\hline \multicolumn{2}{|c|}{ Wood structures } & W & 0.140 & 0.207 & 0.447 & 0.640 & 0.860 \\
\hline
\end{tabular}

Table 2 shows the behaviour modifiers adopted here for masonry and reinforced concrete buildings, which are the most frequent building types in the study area. Modifiers and their specific ranges and values were fixed according to expert opinions, after discussion with professionals such as architects and civil engineers who have expertise in the built environment of the city. The regional modifier is defined as a function of the age of the building and it takes values between +0.234 for buildings constructed before 1940, and -0.088 for buildings built after 1994. The behaviour modifier is composed of a building modifier and a location modifier. The building modifier considered specific building features, such as those related to the number of stories, height and plan irregularities, and the state of preservation or maintenance. Because of this modifier, the vulnerability index of high-rise buildings may have a penalty of up to +0.08 
units, while low-rise buildings may have a bonus of up to -0.02 units. The location modifier can be used to consider differences in height relative to contiguous buildings and the relative position within the block. In this respect, three situations are considered: intermediate, corner and header. In contrast to intermediate and corner buildings, which have two adjacent buildings, a header building only has one adjacent building.

\begin{tabular}{|c|c|c|c|}
\hline Behavior factors & & Parameters & Scope \\
\hline $\begin{array}{l}\text { Height or number } \\
\text { of floors }\end{array}$ & $\begin{array}{l}\text { Reinforced } \\
\text { concrete }\end{array}$ & $\begin{array}{l}\text { Low }(1 \text { or } 2) \\
\text { Medium }(3,4 \text {, or } 5) \\
\text { High }(\geq 6) \\
\text { Low }(1 \text { or } 2) \\
\text { Medium }(3,4 \text {, or } 5) \\
\text { Hiah }(\geq 6)\end{array}$ & $\begin{array}{l}-0.02 \\
+0.02 \\
+0.06 \\
-0.04 \\
0 \\
+0.08\end{array}$ \\
\hline \multicolumn{2}{|l|}{ Preservation rate } & $\begin{array}{l}\text { Good } \\
\text { Bad }\end{array}$ & $\begin{array}{l}-0.04 \\
+0.04\end{array}$ \\
\hline \multicolumn{2}{|l|}{ Horizontal irregularity } & $\ldots$ & +0.04 \\
\hline \multicolumn{2}{|l|}{ Vertical irregularity } & $\ldots$ & +0.02 \\
\hline \multicolumn{2}{|l|}{ Location modifier. } & Intermediate & -0.04 \\
\hline \multicolumn{2}{|l|}{ Position } & $\begin{array}{l}\text { Corner } \\
\text { Header }\end{array}$ & $\begin{array}{l}+0.04 \\
+0.06\end{array}$ \\
\hline \multirow{2}{*}{\multicolumn{2}{|c|}{$\begin{array}{l}\text { Location modifier: } \\
\text { Elevation }\end{array}$}} & $\begin{array}{l}\text { Difference in height } \\
<2 \text { floors }\end{array}$ & +0.02 \\
\hline & & $\begin{array}{l}\text { Difference in height } \\
\geq 2 \text { floors }\end{array}$ & $\begin{array}{l}-0.04 \div \\
+0.04\end{array}$ \\
\hline
\end{tabular}

\subsection{Physical damage}

Concerning the expected physical damage, once complete damage probability matrices (DPM) have been obtained, let $p_{j}=\mathrm{P}\left(\mathrm{j} \mid \mathrm{I}, \mathrm{V}_{\mathrm{l}}\right)$ be the probability of the damage grade $\mathrm{j}$, for a given intensity, $\mathrm{I}$, and a vulnerability index $V_{1}$. Then the mean damage grade is defined as:

$$
\mu_{D}\left(I, V_{I}\right)=d *\left(I, V_{I}\right)=\sum_{J=0}^{5} j P\left(j \mid I, V_{I}\right)=\sum_{J=0}^{5} j p_{j}
$$


Giovinazzi (2005) calibrated a semi-empirical damage function linking macroseismic intensity (I), the vulnerability index $\left(V_{1}\right)$, and the mean damage grade $\left(\mu_{D}\right)$. The following equation defines these damage functions:

$$
\mu_{D}=d^{*}=2.5\left[1+\tanh \left(\frac{I+6.25 V_{I}+13.1}{2.3}\right)\right]
$$

Figure 1 shows several examples of this function for the building types of the Ciutat Vella district. The central value, that is, the most likely vulnerability index, has been used to depict these curves (see also Table 1).

Once the mean damage grade is known, the DPM can be retrieved from the assumption of the binomial statistical distribution. However, for methodological purposes, and, to avoid the discrete nature of the binomial distribution, the continuous probability Beta distribution was preferred. Beta parameters were obtained so that the Beta distribution fitted the Binomial one. The probability density function (pdf) is given by the following equation:

$$
p_{\beta}(x)=\frac{\Gamma(t)}{\Gamma(q) \Gamma(t-q)} \frac{(x-a)^{q-1}(b-x)^{t-q-1}}{(b-a)^{t-1}} \quad a \leq x \leq b
$$

In this equation $\Gamma(\cdot)$ is the gamma function, $x$ is the independent variable, which takes values between $a$ and $b$ that define the domain of the pdf function, and $t$ and $q$ are the parameters of the Beta distribution. $t$ is related to the dispersion of the distribution. A value of $t=8$ makes the Beta distribution compatible with the Binomial distribution. $a$ and $b$, which are related to the damage grades, are set to $a=0$ and $b=5$, because 5 non-null damage grades are considered. Finally, the following equation links the mean damage grade $\mu_{\mathrm{D}}$, and the parameters $q$ and $t$ of the Beta distribution (Milutinovic and Trendafiloski, 2003). 


$$
q=t\left(0.007 \mu_{D}^{3}-0.052 \mu_{D}^{2}+0.2875 \mu_{D}\right)
$$

The probability, $P_{\beta}(x)$, that a damage value is less than or equal to $x$ is defined by the integral between $a$ and $x$ of the pdf defined in Equation (1); that is:

$$
P_{\beta}(x)=\int_{a}^{x} p_{\beta}(\varepsilon) d \varepsilon
$$

And thus, the probability of the $k$ damage grade, $k=0, \cdots, 5$ can be obtained by means of the following equation:

$$
p_{k}=P_{\beta}(k+1)-P_{\beta}(k) \quad k=0, \cdots, 5
$$

Thus, for each building, defined by means of its vulnerability index, $V_{1}$, and for each earthquake scenario, defined by means of an EMS-98 macroseismic intensity, I, Equation (2) can be used to obtain the mean damage grade, $\mu_{D}$, and Equations (3), (4), (5) and (6) can be used to obtain the specific DPM, that is, the probabilities of each damage grade.

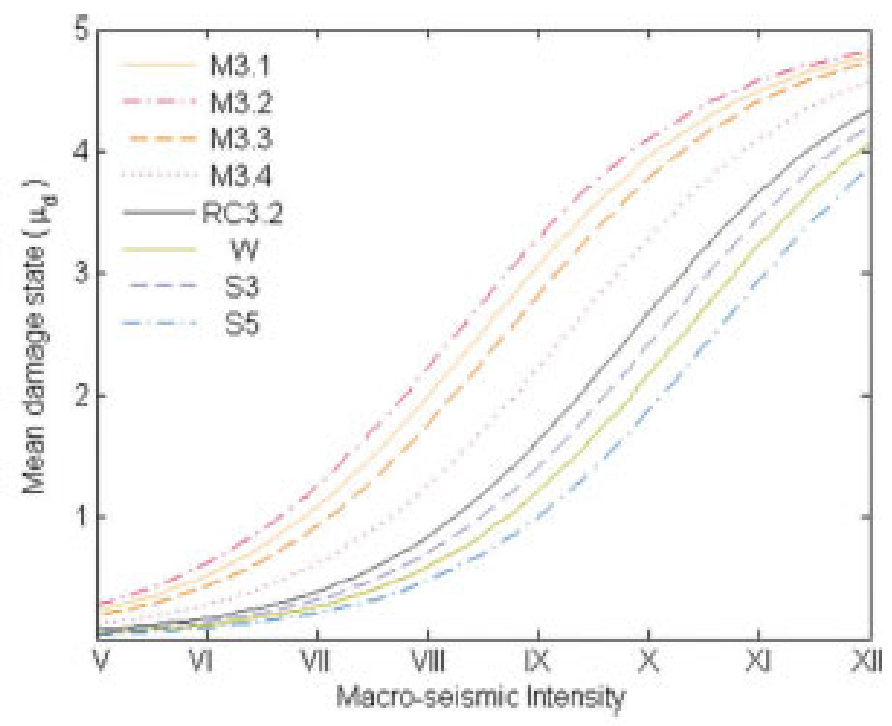

Figure 1. Semi-empirical damage functions for the building types of Ciutat Vella district. The central value, that is, the most likely vulnerability index, was used to depict these curves (see also Table 1). 


\subsection{Other damage-induced effects}

The probabilities of the damage grades, 3, 4 and 5, labelled as Heavy, Very-Heavy and Destruction are essential to evaluate other induced effects, such as damage to population, debris volumes, and the economic cost of physical damage. Note that the economic cost is defined here as the repair cost. Obviously, for emergency planning and management it is vital to know these induced effects. This section is devoted to describing how these key factors are assessed.

\subsubsection{Damage to population}

The number of human victims among the population, including those injured, killed or made homeless by earthquakes, is directly related to the physical damage suffered by the buildings in which the population lives. This study applies a model of victims to estimate these sensitive numbers. The basic data required are the probabilities of occurrence of a damage state, and the density and distribution of the population at the time of the earthquake. It is very important to know, or to estimate, the number of people in each damaged building. This number depends not only on the number of inhabitants and the number of dwellings, but also on the season of the year, the day of the week, and the time at which the earthquake occurs. Details on the estimation of the distribution of victims according to the type of building, the type of earthquake and the time of occurrence are well-described in Vacareanu et al. (2004).

Given a building type and a category of casualties, Coburn and Spence $(1992,2002)$ modelled the corresponding number of victims $\left(K_{S}\right)$ as:

$$
K_{S}=C \cdot[M 1 \cdot M 2 \cdot M 3 \cdot(M 4+M 5 \cdot(1-M 4))]
$$

where $C$ is the number of collapsed buildings and is obtained by multiplying the number of buildings of the class considered by the corresponding probability of the Complete damage state. Note that for victim 
estimation purposes, it is understood that Complete damage corresponds to 4. Very heavy and 5. Destruction, so that the probability used to calculate the number of collapsed buildings is the sum of the probabilities of the damage grades 4 and 5 .

Then, for each building, $\mathrm{M} 1$ is the number of dwellers, $M 2$ is the occupancy rate, and $M 3$ is the percentage of occupants of the building who are trapped due to its collapse. Thus, the product $M 1 \cdot M 2 \cdot M 3$ is the number of people that the earthquake has left trapped inside the damaged building. Finally, M4 and M5 are the parameters used to estimate the distribution of the categories of victims.

For each category of victims, M4 gives the percentage of trapped people who will suffer each type of damage. M5 only takes values other than zero in the case of deceased people. In this case, M4 represents the number of deaths caused directly by the collapse of the building, and M5 allows for post-earthquake mortality.

For masonry and reinforced concrete buildings, values were adopted (see Table 3) based on the recommendations of Vacareanu et al. (2004), and Coburn and Spence (1992). These values correspond to an earthquake that occurred during the night on a winter weekday, assuming that this corresponds to the maximum occupancy rate for residential buildings. Note the different values of M4 according to the severity of the injured, as well as the high damage potential of reinforced concrete buildings compared to masonry buildings.

Table 3. Values adopted for the parameters of Equation (7).

\begin{tabular}{|c|c|c|c|c|c|c|c|}
\hline \multirow[b]{3}{*}{$\begin{array}{l}\text { Building } \\
\text { typologies }\end{array}$} & \multicolumn{7}{|c|}{ Parameters for human losses calculation } \\
\hline & \multirow[b]{2}{*}{$\begin{array}{l}\text { M2 } \\
(\%)\end{array}$} & \multirow[b]{2}{*}{$\begin{array}{l}\text { M3 } \\
(\%)\end{array}$} & \multicolumn{5}{|c|}{ M4 (\%) } \\
\hline & & & $\begin{array}{l}\text { Slightly } \\
\text { injured }\end{array}$ & $\begin{array}{l}\text { Injuries that require } \\
\text { hospitalization }\end{array}$ & $\begin{array}{c}\text { Seriously } \\
\text { injured }\end{array}$ & Deaths & $\begin{array}{l}\text { M5 } \\
(\%)\end{array}$ \\
\hline $\begin{array}{l}\text { Unreinforced } \\
\text { masonry }\end{array}$ & 80 & 5 & 30 & 30 & 25 & 15 & 60 \\
\hline $\begin{array}{l}\text { Reinforced } \\
\text { concrete }\end{array}$ & 80 & 50 & 10 & 40 & 40 & 40 & 90 \\
\hline
\end{tabular}


In addition to the number of people who may die or suffer different kinds of injuries, another important aspect of a disaster is the number of people who lose their homes. This number is a figure that must be considered when designing emergency plans and recovery strategies, since spaces must be provided to accommodate these people for a certain, sometimes long, period of time. A dwelling is considered ruined or uninhabitable when its level of degradation prevents its normal use as a home. Our model, based on Coburn and Spence (2002), considers that a building is not habitable when the damage grades are equal to or greater than 3 (Heavy or Severe damage), since it is assumed that this damage grade disables the use of the building as a dwelling. Specifically, it is assumed that $90 \%$ of the dwellings in buildings that suffer Heavy damage, grade 3, and $100 \%$ of those that belong to buildings with Complete damage (grades $4+5)$ are not habitable. The number of homeless people in a building $i$ of typology $t\left(N p h_{i t}\right)$ is defined as:

$$
N p h_{i t}=N p v_{i t} \cdot N v i v_{i t}\left[0.9 P_{i t}(\text { Severe })+P_{i t}(\text { Complete })\right]
$$

where $N p v_{i t}$ is the number of people per dwelling in building i of typology $t, N v i v_{i t}$ is the number of dwellings in the building, and $P_{i t}$ (Severe) and $P_{i t}$ (Complete) are the probabilities of damage states Severe and Complete respectively. Thus, the quantity $\operatorname{Nviv}_{i t}\left[0.9 \cdot P_{i t}(\right.$ Severe $)+P_{i t}($ Complete $\left.)\right]$ defines the number of dwellings in building $i$ of type $t$ that become unusable. Recall that for the application of this model, only four damage states are considered, since in Equation (8) the 3. Severe damage grade corresponds to the 3. Heavy damage state and damage grades 4. Very Heavy and 5. Destruction, are grouped in the new 4. Complete damage grade. In addition, these four damage states are used in the CSBM or LM2 methods.

\subsubsection{Economic cost}

The economic cost of a disaster is another important parameter that is not easy to assess. It is clear that the financial impact of an earthquake disaster goes beyond the cost of the replacement of damaged goods and includes, among many other factors, the impact of the seismic crisis on productive activity, the recovery of the functioning of companies and financial institutions, and the reestablishment of pre-crisis rates 
of economic growth. However, in spite of rates established by insurance companies as compensation for physical damage to persons, including death, it is not appropriate to assess the economic cost of recovering the injured and, particularly, the economic cost of the deaths. Nevertheless, there is broad consensus that the dimension of a disaster is directly related to its economic cost. In this section, an approach to a pecuniary estimation is presented. The quantitative approach only evaluates the reposition cost of damaged buildings, including the structure and contents. Even this drastic simplification in the assessment of the monetary value of an earthquake scenario is not without difficulty, since it is based on what is known as the "replacement cost".

The retrofitting cost of damaged buildings depends on their level of degradation. All the damage grades or states, other than Null, contribute to a greater or lesser extent to degrading the building and, therefore, also have an impact on the economic loss. Thus, for a building $(j)$ of type $(t)$, the parameters involved in the assessment of the probability of the economic repair cost are as follows. 1) The cost $V c_{t}$ of the unit $\left(m^{2}\right)$ of damaged area, which is assumed to be the same for all buildings of the same type $(t)$, and 2$)$ the number of square meters to be repaired or replaced.

In turn, the number of square meters to be replaced for each damage grade or state depends on the product of the number of square meters of the building $\left(A r e a_{j t}\right)$, the probability of the damage state $k$ $\left(P_{j t k}\right)$, and the equivalent meters in repair cost of each damage grade $\left(R C_{t k}\right)$. Obviously, the contribution of all damage states must be added together. In addition, when applied to a large population of buildings, these numbers must be summed for all buildings (j) of each type, and for all types $(t)$ of buildings, which leads to the following evaluation model:

$$
\operatorname{Cos} t=\sum_{t=1}^{N t}\left\{V c_{t} \sum_{j=1}^{N e t}\left[\operatorname{Area}_{j t} \sum_{k=1}^{N s} P_{j t k} \cdot R C_{t k}\right]\right\}
$$


where $R C_{t k}$ is the cost of damage caused by the degree of damage $k$ in buildings of type $t$, and is defined as a percentage of the unit cost of $m^{2} . P_{j t k}$ is the probability of damage state $k$ of building $j$ of type $t$, and is obtained from the corresponding damage probability matrix. Ns is the number of damage states of the Null damage state. Area ist $_{\text {is }}$ the area constructed in square meters of a building $j$ of type $t$. Net is the number of buildings of type $t$, and $V c_{t}$ is the estimated cost of the square meter for buildings of type $t$. The value of $V c_{t}$ must be close to the actual costs of materials and labour needed to restore the damaged property, but $\mathrm{V} c_{t}$ does not include the price of the land. Finally, $N t$ is the number of types of buildings considered in our BTM.

In addition to economic losses due to deterioration of the building, the economic losses due to damage to contents are also considered. Our model is simple, and it is based on the ATC-13 (1985) report (see also McCormack and Rad, 1997). It is assumed that the content value of residential buildings is $50 \%$ of the building replacement cost. The total cost of direct economic losses (Tcost) will be the sum of both quantities, that is, 1.5 times the value obtained in Equation (9).

The approximation that $V c_{t}$ in Equation (9) is the same for all building types is usually assumed, since the materials, techniques and labour used nowadays have very similar costs. This assumption, which is very reasonable for typical residential buildings, would not be adequate in another case such as, for instance, for special or cultural heritage buildings.

\subsubsection{Debris}

In addition to the economic impact, direct physical damage generates debris that can be estimated from the damaged surface that needs to be repaired, rebuilt or retrofitted. These induced effects are not directly related to the vulnerability indices or to the mean damage grade, as they depend on the size and number of damaged buildings in each neighbourhood, as well as the magnitude of the overall destroyed or deteriorated area. 
Both HAZUS 99 (FEMA / NIBS 2002) and guidelines related to the Risk-UE project (Vacareanu et al., 2004) give special importance and usefulness to the estimated volume of debris generated. This estimation is particularly interesting and useful in old downtown areas, where there is a high density of urban fabric and the main streets and roads are narrow. Even in normal conditions, it can be difficult to move around by car, and even harder to pass through these streets with the kind of vehicles involved in emergency care. Therefore, the forecast of the volume of debris generated in the different scenarios and methods considered here becomes an essential factor to plan access to the affected population, to draw up evacuation routes, and even define areas for the establishment of victim and homeless assistance camps.

The model for the estimation of debris considers different types of ruins. For example, an adobe building will clearly generate debris that is very different from that produced by steel or other modern constructions. Moreover, a typical reinforced concrete building includes masonry elements and, consequently, the same type of building can give rise to different types of debris that will be directly related to the construction materials used in the building. The amount of debris resulting from a building that has experienced an earthquake will be a function of the degree of damage it has suffered. Therefore, for a building (j) of type $(t)$, for each type of debris $(e)$ and each damage grade $(k)$, the contribution to the volume of debris will be given by the following equation:

$$
D_{e j t k}=A_{j t} \cdot W_{e t} \cdot F_{e t k}
$$

where $D_{\text {ejtk }}$ is the contribution to the total weight of debris of type $e$ by the building $j$ of type $t$, when the building has a damage grade $k ; A_{j t}$ is the constructed area of building $j$ of type $t$; and $W_{e t}$ is the unit weight $\left(t o n / \mathrm{m}^{2}\right)$ of the type of material $e$ for the type of building $t . F_{e t k}$ is the fraction of the unit weight that results in ruin for this type of debris $e$, for this type of building $t$ that occurs when the building has a damage grade $k$. For a seismic scenario, the frequency of debris will result from the product between this amount $D_{\text {ejtk }}$ and the probability that the building $j$ of type $t$ suffers a damage grade $k\left(P_{j t k}\right)$. 
Let us consider, for instance, a masonry building containing various materials such as brick and mortar loading walls, metal pillars and reinforced concrete slabs. It is estimated that the weight of brick and mortar per square meter of usable area is 0.5 tons and that, when the building suffers a Moderate damage grade, $10 \%$ of this material causes debris of this type. If this building consists of $400 \mathrm{~m}^{2}$ of useful area, the likely amount of debris of this type, if the building is in a scenario where the probability of moderate damage is $30 \%$, will be: $400 \times 0.5 \times 0.10 \times 0.30=6$ tons of brick and mortar debris.

In the general case of a set of buildings of different types that can generate debris of different kinds, located in places with different probabilities of damage states, the integral or sum of the elements defined in Equation (10) must be calculated, multiplied by the probability of the corresponding damage state, for all types of debris, for all types of buildings, and for all damage states. That is, the total volume of debris $\left(E S_{\text {Total }}\right)$ is defined by the equation:

$$
E s_{\text {total }}=\sum_{t=1}^{N t}\left(\sum_{j=1}^{N e t}\left\{\sum_{e=1}^{N d}\left[\sum_{k=0}^{N s} A r e a_{j t} \cdot W_{e t} \cdot F_{e t k} \cdot P_{j t k}\right]\right\}\right)
$$

where the $k$ index runs the different damage states between 0 (Null) and Ns (Complete), e goes through the types of debris and varies from 1 to the number $N d$ of types of debris; $j$ holds for the number of buildings of typology $t$ and ranges from 1 to the number of buildings of typology $t$, Net; and $t$ contains the different typologies between 1 and the number of different typologies, $N t$.

The models used here are simplified and consider only two types of buildings and two types of debris. The values of the parameters in Equations (10) and (11) have been taken from Vacareanu et al. (2004), which, in turn, were taken from HAZUS 99 (FEMA/NIBS 2002). When these references provide a range of variability, the mean value has been adopted. 


\section{Application to Ciutat Vella}

\subsection{The Ciutat Vella District}

Barcelona is the political and economic capital of Catalonia, and the second city of Spain, after Madrid. It is located on the north-eastern Mediterranean coast of Spain. A mountain range, called Collserola mountain, and two rivers, the Besos to the North and Llobregat to the South, define the city's geographical borders. Barcelona has an area of about $100 \mathrm{~km}^{2}$ and 1.6 million inhabitants. The average population density is 15,706 inhabitants per $\mathrm{km}^{2}$. Barcelona, like most modern cities, is comprised of neighbourhoods and districts, which constitute the basic administrative territorial divisions of the city. These areas are the result of the evolution and growth of the city and the historical groupings of its population. Specifically, the city is comprised of ten districts, the oldest being Ciutat Vella. Ciutat Vella means "old city" and it contains the downtown area built around the early settlement.

In the Iberian era, one of the first two settlements in the environment of Barcelona was in mount "Tàber", known as Barcino in the $3^{\text {rd }}$ century B.C. (Figure 2), with between 10,000 and 15,000 inhabitants. This would later be destroyed in the $3^{\text {rd }}$ century A.D. by invading German tribes. Barcino was rebuilt, fortified and began to grow in the $8^{\text {th }}$ to $11^{\text {th }}$ century, when the city passed into the hands of the Muslims, Carolingians and Counts, reaching about 80 hectares and around 20,000 inhabitants. In 1359, Barcelona had 34,339 inhabitants (according to the Barcelona City Council's Municipal Institute of Information Technology, IMI) and it is then, when in addition to the walled enclosure built in the thirteenth century, a third wall enveloped the whole district of "El Raval". In 1753, a new neighbourhood, "La Barceloneta", was created outside the walls, to solve the problem of people evicted due to the demolition of part of the neighbourhood of "Ribera", near the fortress of "La Ciutadella" (Figure 2). The population of the city continued to grow within a very limited area, rising from 118,000 inhabitants in 1835 to more than 173,000 in 1849. Buildings had to increase in height, while houses became smaller (Solé, 1975). In 1856, the urban 
plans that established the reform of the district of Ciutat Vella began as a mechanism to correct the problems of high density, poor sanitary conditions, and the disorder of the buildings within the space of the wall. Between 1858 and 1868, the city walls were demolished. The building pressure of the district of Eixample (which means widening) and its continuous densification were translated directly into Ciutat Vella, which enabled the buildings to grow in height, adding a final phase of internal densification with a dramatic impact on the population density.

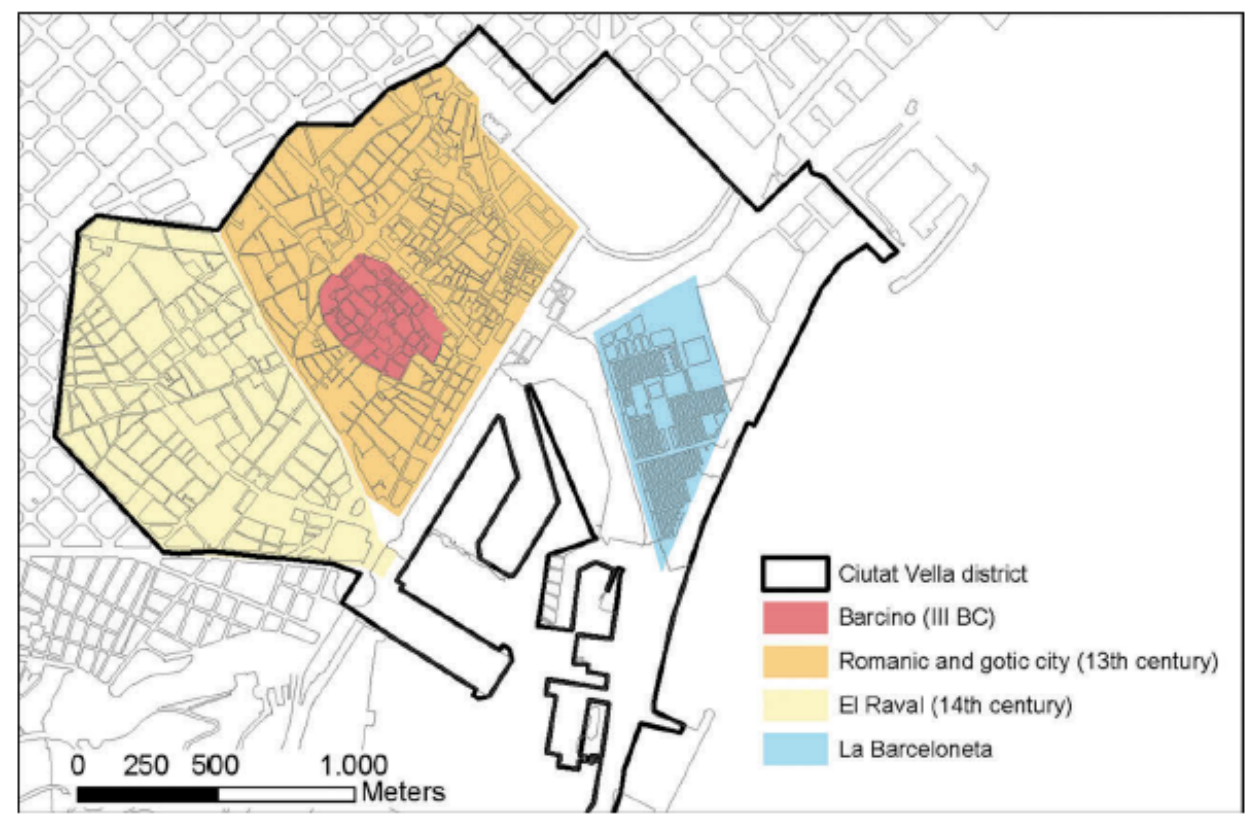

Figure 2. Evolution of the Ciutat Vella district and neighborhoods.

Currently, the Ciutat Vella district occupies $4 \%$ of the city's surface, and makes up $6.2 \%$ of the total population, with 100,115 inhabitants and an average density of 22,918 inhabitants per $\mathrm{km}^{2}$. Ciutat Vella is one of the districts with the highest net residential density of the city (774 inhabitants per residential hectare). This is a measure of population density expressed as people per hectares of net residential area, which includes only residential plot areas. The district contains four neighbourhoods: 1. "Raval", 2. "Gòtic", 3. "Barceloneta" and 4. "Sant Pere, Santa Caterina i la Ribera". This last neighbourhood will be called by its former name "Parc" in this paper (see Figure 2 and Table 4). 
The building stock of the district, with a total of 5,755 buildings ( $8 \%$ of the city), covers $67 \%$ of the district's surface. Data on the buildings that were used in this study have been extracted by crossing the available information on the built cadastral plots, and structural information provided by the City Council of BarceIona's Municipal Institute of Information Technology (IMI). This information includes the age of the buildings, structural typology, number of floors, state of conservation, and population census (registered citizens in each building). The analysis of vulnerability and direct physical damage and the estimation of effects on the population was undertaken on the basis of 4,993 residential buildings; over $87 \%$ of the total number of built plots, which constitutes a highly representative amount of information available for this study (Table 4). Notably, many built plots in the Ciutat Vella are cultural heritage buildings that have not been included here, since only residential buildings were considered.

Table 4. Distribution, by neighborhoods (Neighb.), of Inhabitants (Inh.), population density, number of residential buildings (Res. Build.) and Dwellings (Dwell.) and inhabitants/ dwelling (Inh./Dwell). The mean year of construction of buildings is also shown.

\begin{tabular}{|c|c|c|c|c|c|c|c|}
\hline \multirow[b]{2}{*}{ Neighb. } & \multirow[b]{2}{*}{ Inh. } & \multicolumn{2}{|c|}{ Population density } & \multicolumn{2}{|c|}{ Resid. Build. } & \multirow[b]{2}{*}{$\begin{array}{l}\text { Inh./ } \\
\text { Dwell. }\end{array}$} & \multirow[b]{2}{*}{$\begin{array}{l}\text { Year of } \\
\text { constr. } \\
\text { (mean) }\end{array}$} \\
\hline & & $\begin{array}{l}\operatorname{lnh} / / \\
\mathrm{km}^{2}\end{array}$ & $\begin{array}{l}\text { Inh/. } \\
\text { (Resid. }^{\text {Ra) }} \text { (F) }^{(*)}\end{array}$ & Build. & Dwell. & & \\
\hline Raval & 47274 & 44210 & 951 & $\begin{array}{c}1 \\
706\end{array}$ & $\begin{array}{c}16 \\
851\end{array}$ & 2.8 & 1895 \\
\hline Gòtic & 15729 & 29424 & 461 & $\begin{array}{c}1 \\
088\end{array}$ & 6450 & 2.4 & 1887 \\
\hline $\begin{array}{l}\text { Barceloneta } \\
\text { Parc }\end{array}$ & $\begin{array}{l}15068 \\
22380\end{array}$ & $\begin{array}{l}13698 \\
20809\end{array}$ & $\begin{array}{c}1117 \\
691\end{array}$ & $\begin{array}{c}846 \\
1 \\
353\end{array}$ & $\begin{array}{c}6850 \\
10 \\
021\end{array}$ & $\begin{array}{l}2.2 \\
2.3\end{array}$ & $\begin{array}{l}1927 \\
1897\end{array}$ \\
\hline $\begin{array}{l}\text { TOTAL } \\
\text { DISTRICT }\end{array}$ & $\begin{array}{l}100 \\
451\end{array}$ & 26517 & 774 & $\begin{array}{c}4 \\
993\end{array}$ & $\begin{array}{c}40 \\
172\end{array}$ & 2.5 & 1900 \\
\hline
\end{tabular}

(") Inh./(Resid. ha) means inhabitants per residential hectare.

The average year of construction of the Ciutat Vella district buildings is prior to 1900 for all neighbourhoods (1887 for the Gòtic neighbourhood, the oldest one), except for Barceloneta, which is 1927. There- 
fore, the average age of buildings is over 100 years (Table 4). Most of the district's buildings are unreinforced masonry (91\%) and reinforced concrete with waffle slabs (5.5\%); both construction types are highly vulnerable to seismic actions. The remaining buildings have steel (slightly over $2 \%$ ) and wood (less than $1 \%)$ structures.

The VIM was implemented building by building for the database available through a Geographic Information System (GIS) that has been adapted to the specific characteristics of the study area. In this article, the results of this study are shown in detail for the district of Ciutat Vella at neighbourhood level and, for each scenario, maps are provided with the geographical distribution of the most likely damage grade or state. Population data is used to calculate scenarios for the number of victims, the injured and people made homeless. Estimates of the volume of debris produced and the economic cost of each specific scenario are also provided.

\subsection{Earthquake Scenarios}

According to the current Spanish seismic code (NCSE-02, 2002), Barcelona is in a seismic region in which the intensity with a probability of occurrence of $10 \%$ in 50 years is VI in the European Macroseismic Scale (EMS-98). The corresponding basic acceleration is $0.04 \mathrm{~g}$.

Ciutat Vella is built on outcrops of Holocene deltaic materials and quaternary materials of thickness between 25 and $17 \mathrm{~m}$. Below this layer of soft soils and above the Paleozoic basement, there is a thick layer of tertiary materials at a depth of $350 \mathrm{~m}$. For seismic demands, intensity increases of 0.5 units can be considered in areas of soft soils (Secanell et al., 2004). According to Secanell et al. (2004), because of the soft soil amplification effects, the VI intensity foreseen in the Spanish code in rock outcrops in Barcelona should be increased by a half unit for Ciutat Vella. Therefore, VI-VII is the intensity with a 475 -year return period, that is the intensity with a $10 \%$ probability of occurrence in 50 years. 
Barcelona Council's Civil Protection Service showed an interest in updating the city's Municipal Action Plan (PAM). To this end, they suggested analysing homogenous scenarios, covering a reasonable range of likely-to-possible earthquakes in the city, in half-degree intervals of intensity. Specifically, in this study on the Ciutat Vella district, deterministic and homogeneous earthquake scenarios are considered. These scenarios are defined by the following EMS-98 macroseismic intensities: V (5), V-VI (5.5), VI (6), VI-VII (6.5) and VII (7).

In this way, the effects of weaker and stronger earthquakes than that corresponding to a 475 -year return period would be analysed. Thus, soft soil amplification effects are not explicitly considered.

A previous Spanish seismic code NCSE-94 (1994) can be used to estimate basic accelerations $\left(a_{b}\right)$ and the return periods (RT) corresponding to a determined macroseismic intensity. To find the basic acceleration corresponding to the seismic scenarios considered, the following equation (NCSE-94 1994) was used:

$$
\log _{10} a_{b}=0.301030 \mathrm{I}-0.2321
$$

where $a_{b}$ is the basic acceleration, which is also usually identified as the effective peak acceleration, and I is the macroseismic EMS-98 intensity. According to Equation (12), the $a_{b}$ value of $0.04 \mathrm{~g}$, assigned to Barcelona, corresponds to a macroseismic intensity of VI. That is, the city is considered to have a low-tomoderate seismic hazard.

The NCSE-94 code provides basic accelerations with a return period of 500 years for all the cities in Spain (0.04 $\mathrm{g}$ for Barcelona), and proposes the following equation to calculate the return periods of other basic accelerations:

$$
\left.a_{b}\right|_{P R=t}=\left.a_{b}\right|_{P R=500}\left[\frac{t}{500}\right]^{0.37}
$$


Where $\left.a_{b}\right|_{P R=t}$ is the basic acceleration with a return period $t$, and $\left.a_{b}\right|_{P R=500}$ is the basic acceleration for a return period of 500 years.

Equations (12) and (13) have been used to calculate the basic accelerations and the corresponding return periods of the analysed seismic scenarios. Table 5 shows the macroseismic intensities of the scenarios considered, together with the corresponding basic accelerations and return periods. After performing the seismic risk assessment for all earthquake scenarios in Table 5, no significant damages are expected in Ciutat Vella for the $\mathrm{V}$ intensity scenario. Then, only the results obtained for the other four earthquake scenarios will be shown.

Table 5. Seismic scenarios considered, in terms of macroseismic intensities, basic acceleration, ab (g units), and return periods, TR (in years).

\begin{tabular}{lcc}
\hline EMS'98 Intensity & $a b(g)$ & TR (years) \\
\hline V & 0.019 & 75 \\
V-VI & 0.027 & 175 \\
VI & 0.040 & 500 \\
VI-VII & 0.054 & 1130 \\
VII & 0.077 & 3000 \\
\hline
\end{tabular}

Table 6. Vulnerability index and mean damage grade for each intensity.

\begin{tabular}{lccccc}
\hline & & \multicolumn{4}{c}{ INTENSITY } \\
\cline { 3 - 6 } Neighborhood & Vulnerability Index & V-VI & VI & VI-VII & VI \\
\hline 1 Raval & 0.905 & 0,853 & 1,197 & 1,621 & 2,057 \\
2 Gòtic & 0.912 & 0,866 & 1,215 & 1,644 & 2,053 \\
3.Barceloneta & 0.848 & 0,702 & 0,994 & 1,364 & 1,772 \\
4 Parc & 0.896 & 0,834 & 1,172 & 1,588 & 2,046 \\
TOTAL DISTRICT & 0.886 & 0.766 & 1.149 & 1.591 & 2.062 \\
\hline
\end{tabular}




\subsection{Vulnerability and physical damage}

The vulnerability of Ciutat Vella buildings indicates an average value of 0.59 for concrete buildings and 0.93 for masonry buildings, which are the most vulnerable. Therefore, it is expected that masonry buildings suffer greater damage grades, because the pattern of vulnerability is transferred to the pattern of damage. For the intensity VII scenario, the Gòtic, Raval and Parc neighbourhoods of the Ciutat Vella district suffer a damage grade slightly above damage grade 2 (Moderate) (Table 6), which implies frequencies of $27 \%, 8 \%$ and $1 \%$ of the states Heavy, Very Heavy and Destruction, respectively (Figure 3).

\subsection{Other induced effects}

\subsubsection{Damage to population}

The model described above was applied to each building, according to Equations (6) and (7), to directly obtain the number of people who were injured, killed or made homeless. All these results correspond to an earthquake at night, which assumes $80 \%$ occupation of the buildings, using reliable and updated information on the number of inhabitants per building provided by the Barcelona Council for over $96 \%$ of the district's buildings.

The results indicate a significant impact on the population. In the worst-case scenario of an earthquake of intensity VII about three per thousand $(0.3 \%)$ of the population of the district would die and nine per thousand $(0.9 \%)$ of the population would suffer injuries of varying severity. These are significant numbers implying hundreds of people. 


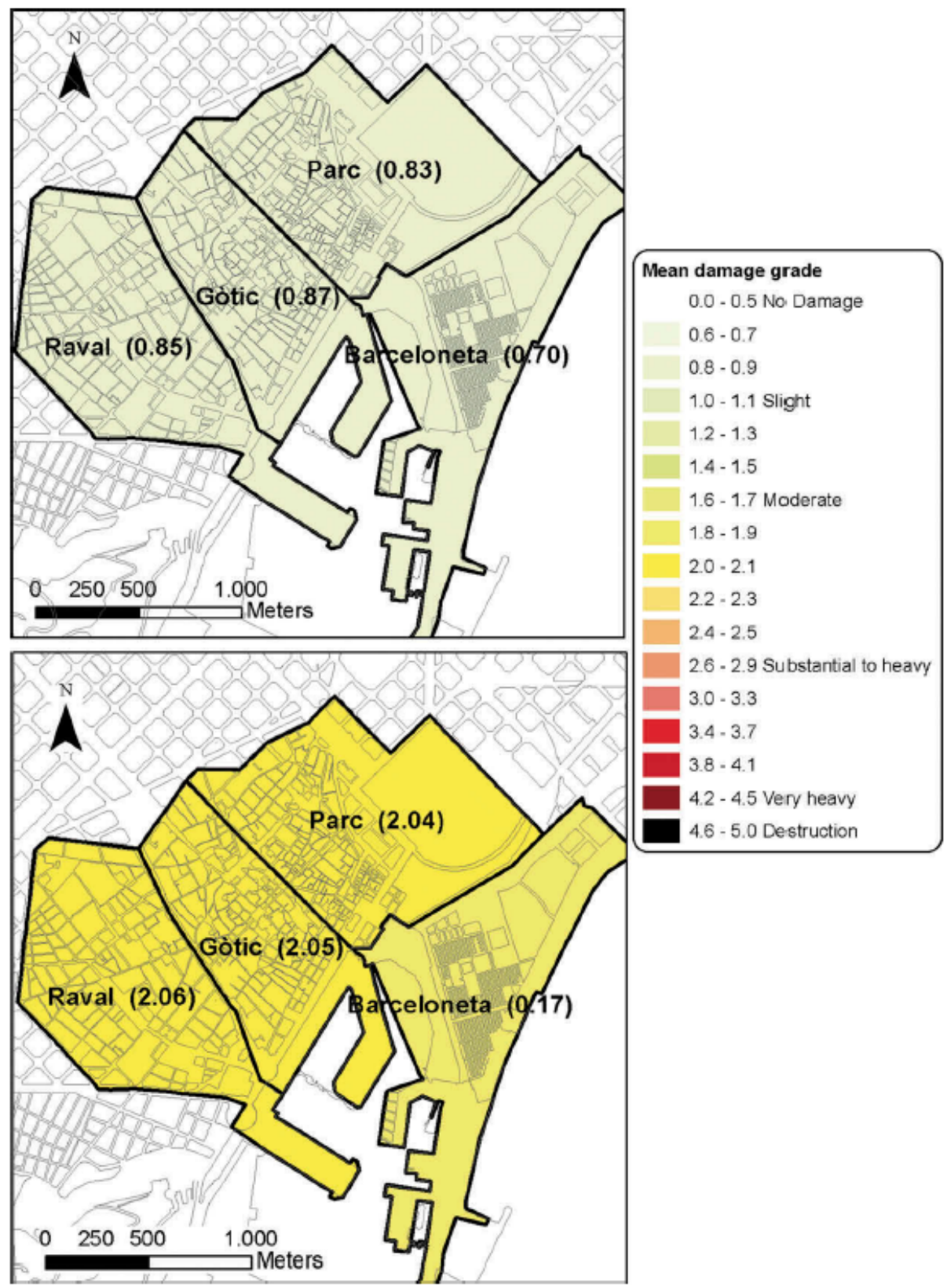

Figure 3. Mean damage grade for intensity V-VI (top) and VII (bottom).

In case of an earthquake of intensity VII, a total of 299 per thousand members of the population of the district would become homeless, that is, over 33,524 people. For earthquakes that are more moderate, the numbers are lower but are also significant and indicate a grave situation. Even for a V-VI intensity earthquake, presumably 32 per thousand people would become homeless (see Table 7 and Figure 4). Recent earthquakes in densely populated areas, with a moderate seismic hazard, such as the Lorca 2011 
earthquake (Alarcón and Benito, 2014), seem to validate these results.

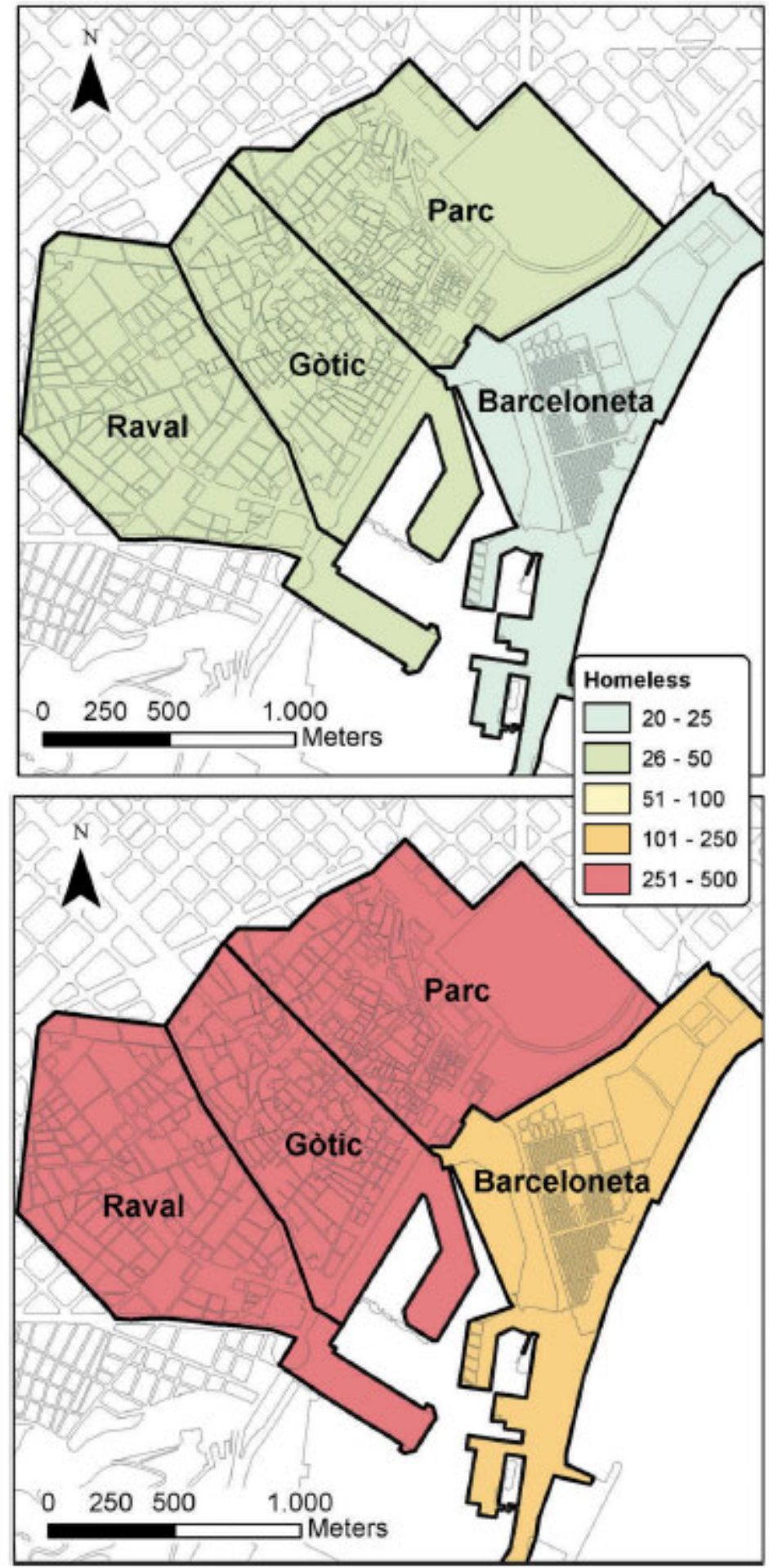

Figure 4. Distribution of homeless (\%o) among neighborhoods for intensity V-VI (top) and VII (bottom). 
The neighbourhood that would be most affected in all cases is "El Raval". This neighbourhood houses almost half the population of the district. For an intensity VII, the expected number of people made homeless would be 15,984 (332 per thousand of its population) (Table 7). Moreover, it is expected that 140 would die (3.0\%o), and 418 would be injured ( $8.8 \%$ \%).

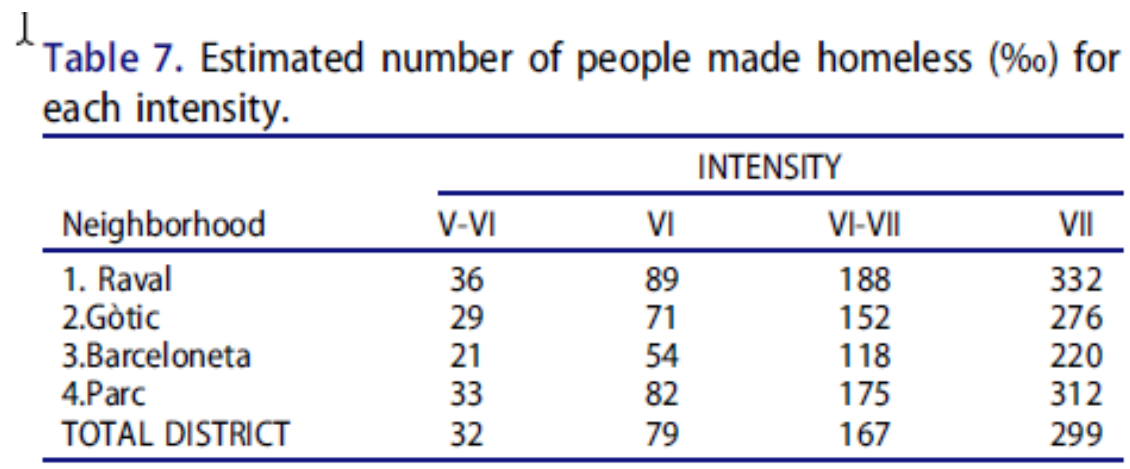

\subsubsection{Economic Cost}

Direct economic losses due to the direct physical damage to buildings have been estimated as the restoration cost of the damaged buildings, according to the model defined by Equation (9). The repair value due to the damage stake $k$ for a building $\mathrm{j}, \mathrm{RCK}, \mathrm{j}$ is given as a percentage or the reposition cost $(V c)$ per square meter (Lantada et al., 2010). In this study, the value adopted for $V c$ is $1,152.11 € / \mathrm{m}^{2}$. This reference value is for a residential building with reinforced concrete structure and waffle slabs (Boletín Económico de la Construcción, 2009).

The expected economic cost of restoring and repairing the buildings that were destroyed or damaged varies according to the seismic scenario considered. While an earthquake of intensity $V$ would not cause significant damage, an earthquake of intensity V-VI would cost almost 296 million euros for the Ciutat Vella district. From this intensity, when the macroseismic intensity increases by half a degree, the total cost of direct economic losses (including the restoration cost of the damaged building and damage to contents) is somewhat less than double (Table 8 and Figure 5). 
Table 8. Total cost in millions of euros (M€).

\begin{tabular}{lcccc}
\hline & \multicolumn{4}{c}{ Intensity } \\
\cline { 2 - 5 } Neighborhood & V-Vl & Vl & Vl-VII & VII \\
\hline 1.Raval & 109 & 218 & 406 & 689 \\
2.Gòtic & 88 & 176 & 328 & 557 \\
3.Barceloneta & 18 & 36 & 69 & 121 \\
4.Parc & 81 & 161 & 301 & 513 \\
TOTAL DISTRICT & 296 & 591 & 1105 & 1879 \\
\hline
\end{tabular}

Regarding the neighbourhoods, the Raval would suffer the greatest economic impact, with an estimated cost of 689 million euros for intensity scenario VII. Moreover, the cost of physical damage to the buildings of only this neighbourhood for intensity V-VI (Table 8) would be over twice the budget of the whole district for the year 2016 (approximately 43 million euros).

\subsubsection{Debris}

According to Equations (10) and (11), the total weight of debris was simulated for the scenarios analysed using the custom GIS tool set for this study. The probabilities of the damage states for each building are taken from the DPM corresponding to the scenarios analysed.

As pointed out above, due to the low probability of damage, no significant volumes of debris are expected for intensity V. However, the Ciutat Vella district would generate a considerable amount of debris in the city in case of higher intensities, for example, 1,161 thousand tons for intensity VII (Table 9 and Figure 6).

In general, the expected debris would mostly be wood and brick (between 50 and $69 \%$ of the total volume generated according to the scenario considered), and the remainder would be concrete and steel. In addition to the great volume of debris, the narrowness of entry roads and of the streets in the district would severely hinder the emergency management. Noticeably, the neighbourhood where the greatest volume of debris would be expected is also El Raval. 
Table 9. Debris generated (thousands of tons).

\begin{tabular}{lcccc}
\hline & \multicolumn{4}{c}{ Intensity } \\
\cline { 2 - 5 } Neighborhood & V-Vl & Vl & VI-VII & VII \\
\hline 1.Raval & 52 & 116 & 235 & 426 \\
2.Gòtic & 42 & 93 & 188 & 341 \\
3.Barceloneta & 9 & 19 & 40 & 76 \\
4.Parc & 39 & 86 & 174 & 318 \\
TOTAL DISTRICT & 142 & 314 & 637 & 1161 \\
\hline
\end{tabular}

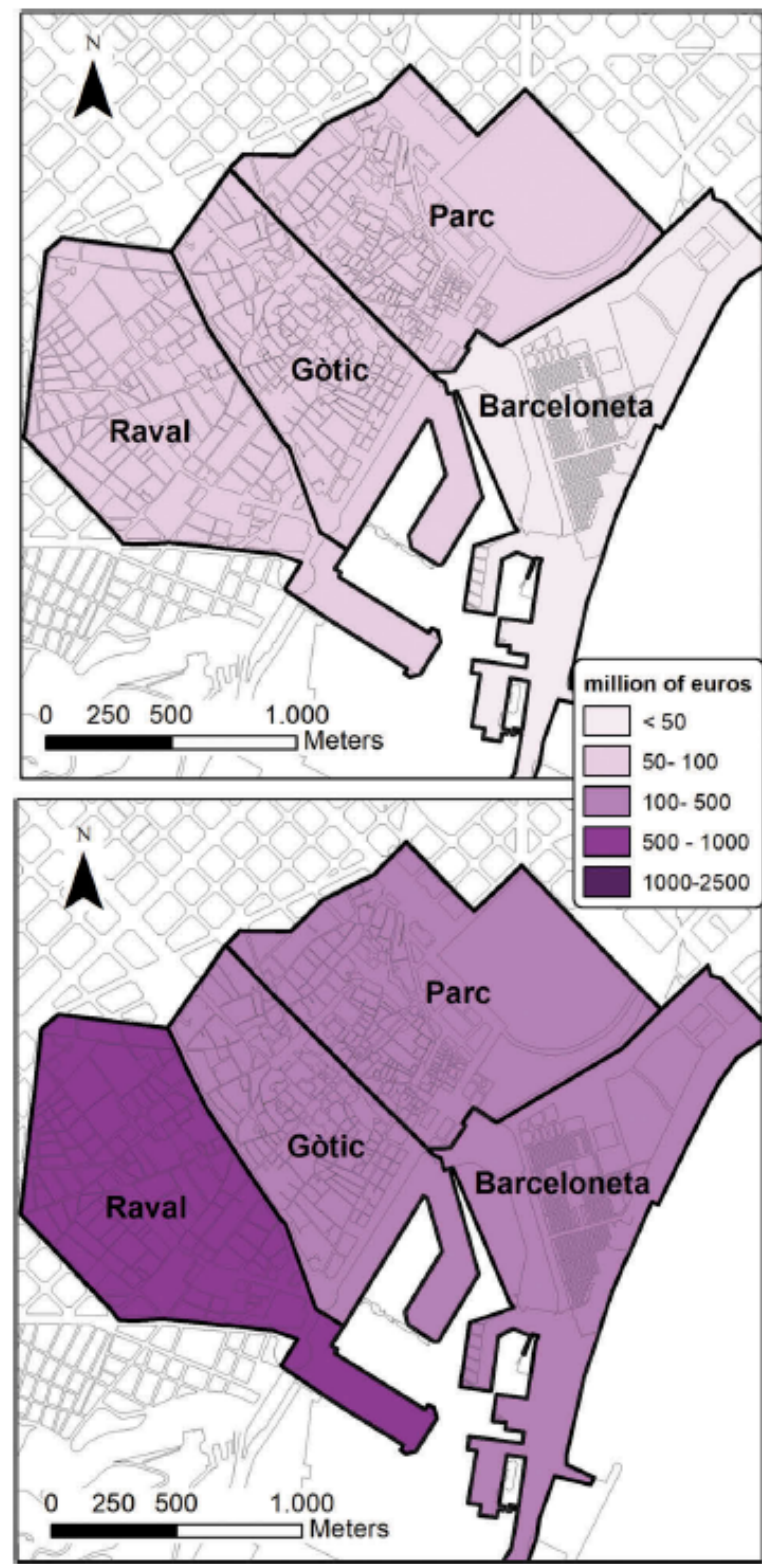

Figure 5. Distribution of total cost in millions of euros (restoration cost of the damaged building and cost due to damage to contents), among neighborhoods for intensity V-VI (top) and VII (bottom).

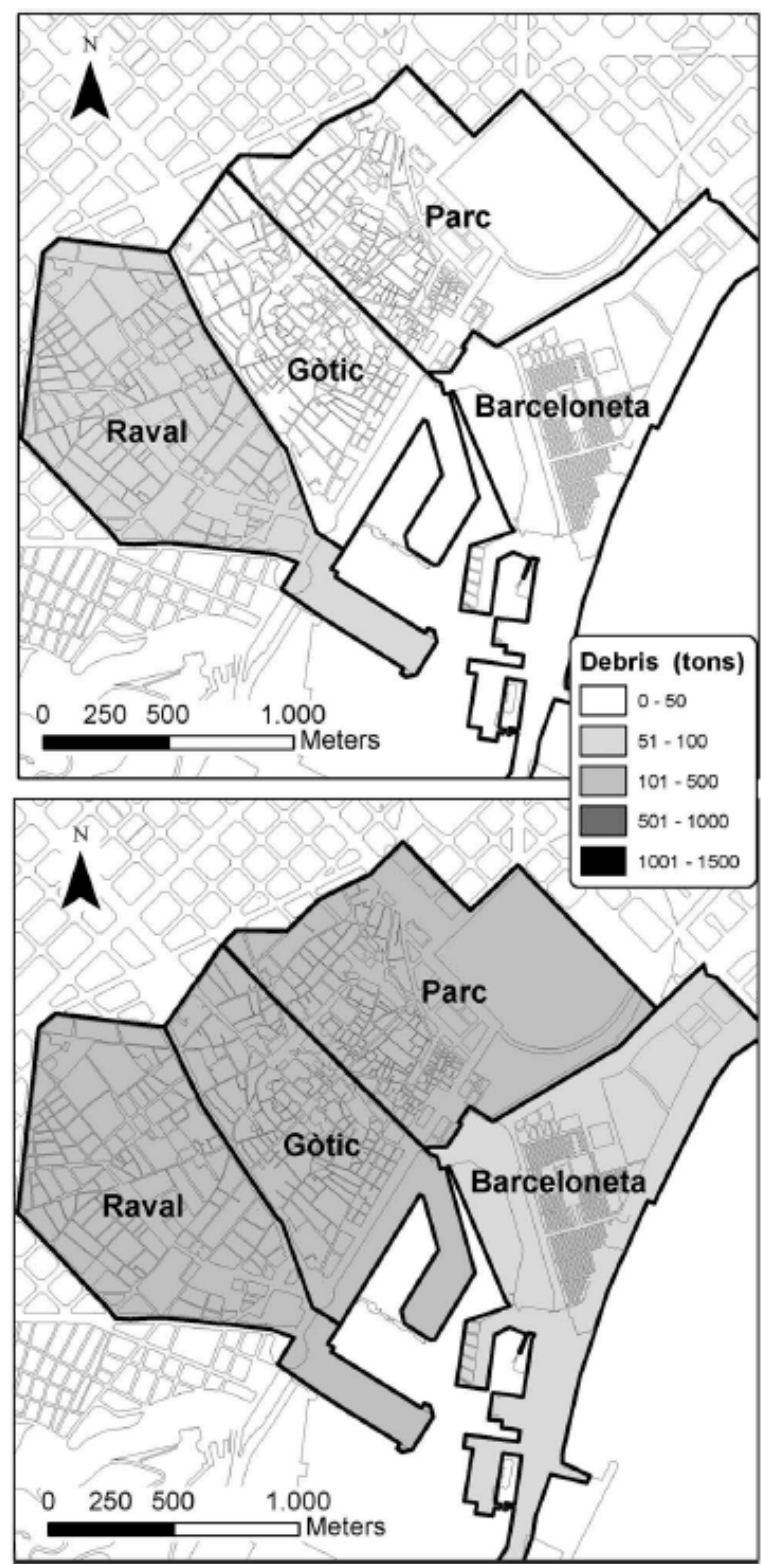

Figure 6. Distribution of debris volume (thousands of tons) among neighborhoods for intensity V-VI (top) and VI (bottom). 


\subsection{Notes on the emergency plan}

On $15^{\text {th }}$ May 1995 at $17: 37$ local time, at a latitude of $40.87^{\circ} \mathrm{N}$ and a longitude of $1.62^{\circ} \mathrm{E}$, in the sea, off the coast between Tarragona and Sitges, an earthquake of magnitude 4.3 occurred. The earthquake caused no material damage but alerted and frightened the population of Catalonia. The impact on the population of Barcelona was disturbing as, moments after the earthquake happened, the communication centres of the official organizations collapsed. An MSK macroseismic intensity of VI was estimated in Barcelona. Consequent to this event, Barcelona City Council began to work on a Municipal Action Plan in case of earthquake. The Municipal Action Plan ("Pla d'Actuació Municipal” [PAM], formerly the PAEM, 2016), in coordination with the Catalonia Seismic Emergency Plan ("Plan de Emergencia Sísmica de Cataluña") (SISMICAT, 2003), was approved in 2002.

Studies on the seismic risk of Barcelona were expanded in the frame of the Risk-EU project, and subsequent joint studies of the Geological Institute of Catalonia and the Technical University of Catalonia (UPC) were carried out in relation to the historical heritage of the city (Irizarry, 2004) and residential buildings (Lantada, 2007). Since then, the Barcelona Civil Protection Service has updated the PAM. This study contributes to the latest update.

Table 9. Debris generated (thousands of tons).

\begin{tabular}{lcccc}
\hline & \multicolumn{4}{c}{ Intensity } \\
\cline { 2 - 5 } Neighborhood & V-Vl & Vl & VI-VII & VII \\
\hline 1.Raval & 52 & 116 & 235 & 426 \\
2.Götic & 42 & 93 & 188 & 341 \\
3.Barceloneta & 9 & 19 & 40 & 76 \\
4.Parc & 39 & 86 & 174 & 318 \\
TOTAL DISTRICT & 142 & 314 & 637 & 1161 \\
\hline
\end{tabular}

The PAM of Barcelona city considers three levels or phases: 1) Alert, 2) Emergency, and 3) Recovery, and defines specific activation criteria. According to the PAM, slight damage to the city would occur from an 
EMS intensity of 5 (V). Therefore, the phase of "Alert" or "intensification of monitoring and information" is considered for an intensity EMS $>=\|$ and $<\mathrm{V}$. The second phase, called "Emergency", considers two levels in relation to the magnitude of the effects on the entire city, beginning emergency phase I for EMS $\mathrm{V}$, and emergency phase II for EMS> = V-VI. In this last case, external assistance is expected to be necessary, because the damage would probably exceed the operational capacity of the municipal groups.

\section{Discussion and conclusions}

Like all of Barcelona city, the Ciutat Vella district is in a low-to-moderate seismic hazard zone, identified in the current Spanish seismic norm NCSE-02 (2002) by a characteristic earthquake of intensity $\mathrm{VI}$ and an associated basic acceleration of $0.04 \mathrm{~g}$ for a return period of 500 years. However, based on the available data and the analyses that were carried out, it can be concluded that this district has a relatively high seismic risk, mainly due to the large accumulation of population, and the old and vulnerable buildings.

The vulnerability of residential buildings is high, mainly due to their age, but also to the lack of knowledge and awareness of the seismic hazard, and the failure to take into account expected seismic actions in the design and construction of buildings. This high vulnerability would cause considerable direct physical damage to buildings, even for low-intensity earthquakes. Consequently, the expected physical damage in the case of moderate earthquakes is significant. For an earthquake of intensity $V$, relevant damage is not expected to occur, but for a scenario of intensity VII, the Gòtic, Raval and Parc neighbourhoods would suffer a damage level slightly above the degree of damage 2 (Moderate) which implies frequencies of $27 \%, 8 \%$ and $1 \%$ of the damage states Heavy, Very Heavy and Destruction respectively. 
As a result of significant damage to buildings and a high concentration of population and socioeconomic activity, significant economic losses and damage to the population are also expected in case of relatively moderate earthquakes. In the worst case of an earthquake of intensity VII, almost three per thousand of the population of the district would die and nine per thousand of the population would suffer injuries of varying severity. In addition to the significant number of victims and injured people who would require immediate attention, the number of people made homeless ( $30 \%$ of the population for intensity VII) is a critical point for post-earthquake emergency management and the subsequent recovery of the normal socio-economic and cultural activity of the city in the medium- and long-term. Recent earthquakes that have occurred in densely populated areas in low-to-moderate seismic hazard regions validate these results.

The economic impact on the district ranges from 296 million euros for an earthquake of V-VI intensity to $€ 1,879 \mathrm{M}$ for an earthquake of intensity VII. Regarding the impact of a seismic crisis on the street and road system, the considerable volume of expected debris stands out (between 142 and 1,161 thousand tons for the V-VI and VII scenarios, respectively). Mobility would be seriously compromised because of the combined effects of the large volume of debris generated and an urban pattern of narrow and irregular streets.

Regarding the neighbourhoods, the Raval would be most affected in all damage aspects, with $33 \%$ of the population being made homeless, and an economic impact of $€ 689 \mathrm{M}$ for the scenario of intensity VII. Due to the increase in infrastructures and services in districts such as Ciutat Vella, the exposed elements are increasing continuously. Therefore, the only way to reduce the seismic risk is to act on reducing vulnerability through seismic regulations, and increase the awareness of the population. 


\section{Acknowledgments}

This study was partially sponsored by Barcelona City Council's Civil Protection Service and by the Spanish Government's Ministry of Economy and Competitiveness (MINECO) and the European Regional Development Fund (ERDF), through projects referenced as: CGL2015-65913-P (MINECO/FEDER, UE). We are grateful to the Civil Defence and Prevention Division of Barcelona's fire brigade for its support and careful review of the manuscript, and to Barcelona City Council's Municipal Institute of Information Technology (IMI) for providing the rich database used in this work.

\section{References}

Alarcón, E. and Benito, B. (2014) Foreword special issue LORCA's earthquake. Special issue: The 2011 Lorca Earthquake \& The Emilia 2012 Earthquakes, Italy. Bull Earthquake Eng (2014) 12:5. 1827-1829. https://doi.org/10.1007/s10518-014-9602-4.

ATC-13. 1985. ATC-13. Earthquake damage evaluation data for California, ATC-13. Applied Technology Council. Redwook City, California. 492 pp.

Barbat, A.H., Pujades, L. G., Lantada, N. 2006. Performance of buildings under earthquake in Barcelona, Spain. Computer-Aided Civil and Infrastructure Engineering, 21(8): 573-593. Erratum (2010). 25(3): 226. Doi 10.1111/j.1467-8667.2010.00660.x

Barbat, A.H., Pujades L.G., Lantada, N., Moreno, R. 2008. Seismic damage evaluation in urban areas using the capacity spectrum method: application to Barcelona. Soil Dyn Earthq Eng 28:851-865

Benedetti, D. and Petrini, V. 1984. Sulla vulnerabilitá sismica di edifici in muratura: Proposte di un metodo di valutazione. L'industria delle Construzioni 149: 66-78 (in italian).

Bernardini, A. 2000. The vulnerability of buildings-Evaluation on a national scale of the seismic vulnerability building. CNR-GNDT. Rome

Boletín Económico de la Construcción. 2009. Revista trimestral de precios del ramo de la construcción. Año LXX, 2o trimestre, no 278, mayo 2009. Oficinas y redacción: Emancipación, Barcelona.

Carnimeo, L., Foti D., Ivorra S. 2015a. On Modeling an Innovative Monitoring Network for Protecting and Managing Cultural Heritage from Risk Events, Key Engineering Materials, 628:243-249, ISSN: 16629795. doi:10.4028/www.scientific.net/KEM.628.243

Carnimeo, L., Foti, D., Potenza, F. 2015b. “On Protecting and Managing Slender Buildings from Risk Events via a Multitask Monitoring Network". In: Proceedings of $7^{\text {th }}$ International Conference on Structural Health Monitoring of Intelligent Infrastructure, July 1-3 2015, Turin, Italy.

Cherif, S., Chourak, M., Abed, M., Pujades L. 2017. Seismic Risk in the city of Al Hoceima (North of Morocco) using the Vulnerability Index Method, applied in Risk-UE project. Natural Hazards, 85:329347 
Coburn, A. and Spence, R. 1992. Earthquake Protection. John Wiley \& Sons, Chichester, England. 355 pp.

Coburn, A. and Spence, R. 2002. Earthquake Protection (2nd edition). John Wiley \& Sons, Chichester, England. 420 pp.Dell'Acqua F., Lanese I., Polli D.A. 2013. Integration of EO-based vulnerability estimation into EO-based seismic damage assessment: a case study on L'Aquila, Italy, 2009 earthquake. Natural Hazards, 68:165-180 DOI 10.1007/s11069-012-0490-0

Feriche, M. 2012. Elaboración de escenarios de daños sísmicos en la ciudad de Granada. Tesis doctoral. Instituto Andaluz de Geofísica y Prevención de Desastres Sísmicos (IAGPDS). Universidad de Granada. 284pp (in Spanish). https://hera.ugr.es/tesisugr/21604794.pdf

Feriche, M., Vida, F., Garcia, R., Navarro, M., Vidal, M.D., Montilla, P., Pinero, L. 2009. Earthquake damage scenarios in Vélez-Malaga urban area (Southern Spain) applicable to local emergency planning. In: Proceedings of the $8^{\text {th }}$ international workshop on seismic microzoning and risk reduction, Almeria, Spain, 15-18 March 2009

FEMA 1997. NEHRP Guidelines for the Seismic Rehabilitation of Buildings. US Federal Emergency Management Agency, FEMA-273, Washington, D.C.

FEMA/NIBS 2002. HAZUS Technical Manual -SR2, Federal Emergency Management Agency, FEMA and National Institute of Building Sciences, NIBS, Washington D.C., Vol. 1, 2, 3.

Ferlito R. and Pizz A.G., 2011 Vulnerability Model of a urban centre. Methodology for a quick evaluation of emergency road network vulnerability. Vol, 28 (4):31-49

Freeman, S.A. 2004. Review of the development of the capacity spectrum method, paper No. 438. J Earthq Technol 41(1): 1-13

Gattulli, V., Potenza, F., Graziosi, F., Federici, F., Colarieti, A., Faccio M. 2015. Distributed structural Monitoring for a Smart City in a seismic area, Key Engineering Materials, 628: 123-135. DOI: 10.4028/www.scientific.net/KEM.628.123

Giovinazzi S. and Lagomarsino S. 2002. WP04. Guidelines for the implementation of the 1 level methodology for the vulnerability assessment of current buildings. Risk-UE report. Genoa (Italy)

Giovinazzi S. 2005. The vulnerability assessment and the damage Scenario in seismic risk analysis. PhD dissertation. The Department of Civil Engineering of the Technical University Carolo-Wilhelmina at Braunschweig and the Faculty of Engineering Department of Civil Engineering of the University of Florence. https://publikationsserver.tu-braunschweig.de/receive/dbbs_mods_00001757 (Last accessed Oct. 11, 2017)

GNDT 1994. Scheda di esposizione e vulnerabilità e di rilevamento danni di primo livello e secondo livello (muratura e cemento armato). Gruppo Nazionale per la Difesa dai Terremoti, Roma (in Italian)

González-Díaz, M. 2010. Evaluación del riesgo sísmico en el Principado de Andorra. Tesis doctoral. Universitat Politècnica de Catalunya.

Goula, X. Dominique, P., Colas, B., Jara, J.A. Roca, A. and Winter, T. 2008. Seismic Rapid Response Systems in the Eastern Pyrenees. The $14^{\text {th }}$ World Conference on Earthquake Engineering, October 12-17, 2008, Beijing, China

Guardiola-Víllora, A. and Basset-Salom, L. 2015.Seismic risk scenarios of the Eixample district in Valencia, Spain. Rev. int. métodos numér. cálc. diseño ing. 2015;31(2):81-90 (in Spanish) 
Grünthal, G., Editor 1998. European Macroseismic Scale 1998, vol. 15. Luxemburg: Centre Européen de Géodynamique et Séismologie, Cahiers du Centre Européen de Géodynamique et de Séismologie;1998.

Irizarry J. 2004. An advanced approach to seismic risk assessment. Application to the cultural heritage and the urban system of Barcelona. Ph.D. thesis. Barcelona: Universitat Politècnica de Catalunya.

Irizarry, J., Lantada, N., Pujades, L.G., Barbat, A., Goula, X., Susagna, T., and Roca, A. 2010. Ground-shaking scenarios and urban risk evaluation of Barcelona using the Risk-UE capacity spectrum based method. Bull Earthquake Eng., 8:201-229. DOI 10.1007/s10518-009-9148-z

ISARD .2006. Información Sísmica Automática Regional de Daños, Interreg IIIA France Spain 2000-2006 programme. (Available at: www.isard.project.eu.)

Jaramillo, N., Carreño, ML, Lantada, N. 2016. Evaluation of social context integrated into the study of seismic risk for urban areas. International Journal of Disaster Risk Reduction, 17, 185-198. Doi 10.1016/j.ijdrr.2016.05.002

Lagomarsino, S., Giovinazzi, S. 2006. Macroseismic and mechanical models for the vulnerability and damage assessment of current buildings. Bull Earthq Eng 4(4):415-443

Lantada, N. 2007. Evaluación del riesgo sísmico mediante métodos avanzados y técnicas GIS. Aplicación a la ciudad de Barcelona. Tesis Doctoral, Universidad Politécnica de Cataluña, Dpto. de Ingeniería del terreno cartográfica y geofísica, Barcelona. Available at:

http://www.tdx.cat/handle/10803/6259

Lantada, N., Pujades, L. G., and Barbat, A. H. 2009a. Escenarios de riesgo sísmico para la Barcelona. Pla d'Actuació d'Emergència Municipal (PAEM) en cas de sisme" en coordinación con el Plan de Emergencia Sísmica de CATaluña (SISMICAT). Barcelona: UPC.

Lantada, N., Pujades, L. G., and Barbat, A. H. 2009b. Vulnerability index and capacity spectrum based methods for urban seismic risk evaluation. A comparison. Natural Hazards, 51:501-524. DOI. 10.1007/s11069-007-9212-4

Lantada, N., Irizarry, J., Barbat, A.H., Goula, X., Roca, A., Susagna, T., Pujades, L.G. 2010. Seismic hazard and risk scenarios for Barcelona, Spain, using the Risk-UE vulnerability index method. Bull Earthquake Eng (2010) 8:201-229. DOI 10.1007/s10518-009-9148-z

Lestuzzi P., Podestà S., Luchini C., Garofano A., Kazantzidou-Firtinidou D., Bozzano C. 2017. Validation and improvement of Risk-UE LM2 capacity curves for URM buildings with stiff floors and RC shear walls buildings. Bull. Earthquake Eng. 15: 1111-1134. DOI. 10.1007/s10518-016-9981-9

Lestuzzi P., Podestà S., Luchini C., Garofano A., Kazantzidou-Firtinidou D., Bozzano C., Bischof P., Haffter A., Rouiller J.D. 2016. Seismic vulnerability assessment at urban scale for two typical Swiss cities using Risk-Ue methodology. Natural Hazards 84: 249-269. Doi 10.1007/s11069-016-2420-z

Maio R. 2016. Seismic vulnerability assessment of historical urban centres: Case study of the old city centre of Faro, Portugal Journal of risk research, Vol.19 (5): 551 -580

McCormack T.C. and Rad, F.N. 1997. An Earthquake Loss Estimation Methodology for Buildings Based on ATC-13 and ATC-21, Earthquake Spectra 13, 605-642. 
Milutinovic, Z.V. and Trendafiloski, G.S. 2003. WP04 Vulnerability of current buildings. RISK-UE project of the EC: an advanced approach to earthquake risk scenarios with applications to different European towns

Montfort, D., Negulescu, C., Roullé, A., Colas, B., Lantada, N., Valcarcel, J., Rodríguez, L., Pujades, L. Barbat, A., Irizarry, J., Susagna, T., Macau, A., Figueras, S., Goula, X. 2012. Seismic risk scenarios in a crossborder zone of the Pyrenees. 12WCEE, Lisbon (Portugal)

Mouroux, P and Lebrun, B. 2006a RISK-UE project: an advanced approach to earthquake risk scenarios with application to different European towns. In: Oliveira CS, Roca A, Goula X (eds) Assessing and managing earthquake risk. Springer, Berlin, pp 479-508

Mouroux, P. and Lebrun, B. 2006b. Presentation of RISK-UE Project. Bull Earthq Eng, special issue: earthquake scenarios for European cities 4(4):323-339

NCSE-94. 1994. Norma de Construcción Sismorresistente Española, Parte General y de Edificación. Comisión Permanente de Normas Sismorresistentes, Real Decreto 2543/1994 del 29 de diciembre de 1994, Boletín Oficial del Estado no 33, miércoles 8 de febrero de 1995. 3936-3980 pp.

NCSE-02. 2002. Norma de Construcción Sismorresistente Española. Parte General y de Edificación, Comisión Permanente de Normas Sismorresistente, Real Decreto 997/2002 del 27 de septiembre de 2002, Boletín Oficial del Estado no 244, viernes 11 de octubre de 2002. Ministerio de Fomento. 35898-35987 pp.

PAEM. 2016. Pla d'actuació d' emergència municipal per al risc sísmic. Document B Manual d'actuació del Pla. Àrea de Seguretati Prevenció del Ajuntament de Barcelona. 147pp (in Spanish) http://www.bcn.cat/bombers/ca/prevencio_emergenciamunicipal.html

Pilone, E., Mussini, P., Demichela, M., Camuncoli, G. 2017. Reprint of: Municipal Emergency Plans in Italy: Requirements and drawbacks. Safety science, vol.:97

Polli, D., Dell'Acqua, F., Gamba, P. 2009. First steps towards a framework for earth observation (EO)-based seismic vulnerability evaluation. Environ Semeiot 2(1):16-30. doi:10.3383/es.2.1.2 ISSN 1971-3460 (online)

Pujades, L.G., Barbat, A.H., González-Drigo, J.R., Avila, J., Lagomarsino, S. 2012. Seismic performance of a block of buildings representative of the typical construction in the example district in Barcelona (Spain). Bull Earthq Eng 10:331-349

Rivas-Medina, A., Gaspar-Escribano, J.M., Benito, B., Bernabé, M.A. 2013 The role of GIS in urban seismic risk studies: Application to the city of Almería (southern Spain) Natural hazards and earth system sciences vol.13 (11):2717 -2725

Secanell, R., Goula, X., Susagna, T., Fleta, J., Roca, A. 2004. Seismic hazard zonation of Catalonia, Spain, integrating uncertainties. Journal of Seismology 8 (1): 24-40.

Simões, A., Bento, R., Lagomarsino, S., Lourenço, P.B. 2016. Simplified evaluation of seismic vulnerability of early 20th century masonry buildings in Lisbon. Source of the Document Structural Analysis of Historical Constructions: Anamnesis, diagnosis, therapy, controls - Proceedings of the 10th International Conference on Structural Analysis of Historical Constructions, SAHC 2016, Leuven (Belgium) 1513-1519pp 
Simões, A., Milošević, J.,Meireles, H.,Bento, R., Cattari, S.,Lagomarsino, S. 2017. Fragility curves for old masonry building types in Lisbon. Bulletin of Earthquake Engineering, vol. 13, Issue 10, 14 October 2015, Pages 3083-3105

SISMICAT.2003. Pla especial d'Emergències a Catalunya. Avalaible at http://www.gencat.net/interior/esc/docs/esc sismicat.pdf (in Catalan)

Sole L. (1975) Geografia de Catalunya. Enciclopedia Catalana (1958-1982). Aedos. ISBN 84-7003-251-8

Sponheuer, W. 1960. Methoden zur Herdtirefenbestimmung in der Makroseismic. Freiberger Forschungshefte: C88, 117.

Tomas, A., Rodenas, J.L., Garcia-Ayllon, S. 2017. Proposal for new values of behaviour modifiers for seismic vulnerability evaluation of reinforced concrete buildings applied to Lorca (Spain) using damage data from the 2011 earthquake. Bulletin of Earthquake Engineering, 15 (9):3943-3962; 10.1007/s10518017-0100-3

Uva G., C. A. Sanjust, S. Casolo \& M. Mezzina (2016) ANTAEUS Project for the Regional Vulnerability Assessment of the Current Building Stock in Historical Centers, International Journal of Architectural Heritage, 10:1, 20-43, DOI: 10.1080/15583058.2014.935983

Vacareanu, R., Lungu, D., Arion, C. and Aldea, A. 2004. WP07. Seismic Risk Scenarios Handbook. Bucharest, Report. Risk-UE Project: 52 pp. 


\section{Figure captions (as a list)}

Figure 1. Semi-empirical damage functions for the building types of Ciutat Vella district. The central value, that is, the most likely vulnerability index, was used to depict these curves (see also

Table 1)

Figure 2. Evolution of the Ciutat Vella district and neighbourhoods

Figure 3. Mean damage grade for intensity V-VI (top) and VII (bottom)

Figure 4. Distribution of homeless (\%o) among neighbourhoods for intensity V-VI (top) and VII (bottom)

Figure 5. Distribution of total cost in millions of euros (restoration cost of the damaged building and cost due to damage to contents), among neighbourhoods for intensity V-VI (top) and VII (bottom)

Figure 6. Distribution of debris volume (thousands of tons) among neighbourhoods for intensity V-VI (top) and VII (bottom) 
Table captions (as a list)

Table 1 Structural typologies and vulnerability classes of dwelling buildings in Ciutat Vella

Table 2 Behaviour modifiers used for masonry and reinforced concrete buildings

Table 3 Values adopted for the parameters of Equation (7)

Table 4 Distribution, by neighbourhoods (Neighb.), of Inhabitants (Inh.), population density, number of residential buildings (Res. Build.) and Dwellings (Dwell.) and inhabitants/dwelling (Inh./Dwell). The mean year of construction of buildings is also shown.

Table 5 Seismic scenarios considered, in terms of macroseismic intensities, basic acceleration, ab (g units) and return periods, TR (in years)

Table 6. Vulnerability index and mean damage grade for each intensity

Table 7. Estimated number of people made homeless (\%o) for each intensity

Table 8. Total cost in millions of euros (M€)

Table 9. Debris generated (thousands of tons) 